
Revue canadienne de chimie

\title{
Experimental and Computational Investigations of Platinum Complexes of Selenium Diimide and Some Novel Selenium- Nitrogen Ligands
}

\begin{tabular}{|r|l|}
\hline Journal: & Canadian Journal of Chemistry \\
\hline Manuscript ID & cjc-2015-0402 \\
\hline Manuscript Type: & Article \\
\hline Date Submitted by the Author: & 13 -Aug-2015 \\
\hline Complete List of Authors: & $\begin{array}{l}\text { Chivers, Tristram; University of Calgary } \\
\text { Laitinen, R.; University of Oulu } \\
\text { Oilunkaniemi, Raija; University of Oulu } \\
\text { Karhu, Aino; University of Oulu } \\
\text { Risto, Maarit ; University of Oulu } \\
\text { Rautiainen, J. Mikko; University of Oulu }\end{array}$ \\
\hline Keyword: & $\begin{array}{l}\text { Platinum, selenium diimide, 77Se NMR spectroscopy, X-ray structures, DFT } \\
\text { calculations }\end{array}$ \\
\hline &
\end{tabular}

\section{SCHOLARONE" \\ Manuscripts}




\title{
Experimental and computational investigations of platinum complexes of selenium diimide and some novel selenium-nitrogen ligands
}

\author{
Aino J. Karhu, Maarit Risto, J. Mikko Rautiainen, Raija Oilunkaniemi, Tristram
} Chivers, and Risto S. Laitinen

A. J. Karhu, M. Risto, J. M. Rautiainen, R. Oilunkaniemi, and R. S. Laitinen. ${ }^{1}$ Laboratory of Inorganic Chemistry, Center for Molecular Materials, P.O. Box 3000, FI-90014, University of Oulu, Finland.

T. Chivers. ${ }^{1}$ Department of Chemistry, University of Calgary, 2500 University Drive NW, Calgary, Alberta, T2N 1N4, Canada

1 Corresponding authors (e-mail: risto.laitinen@oulu.fi, tel. +358 (294) 481611; chivers@ucalgary.ca, tel. +1 (403) 220-5741 
Abstract: The reaction of selenium diimide $\mathrm{Se}[\mathrm{N}(\mathrm{t}-\mathrm{Bu})]_{2}$ and $\mathrm{PtCl}_{2}$ afforded an $N, N^{\prime}$-chelated complex $\left[\mathrm{PtCl}_{2}\left\{N, N^{\prime}-\mathrm{Se}[\mathrm{N}(\mathrm{t}-\mathrm{Bu})]_{2}\right\}\right](\mathbf{1})$ in good yield and $\left[\mathrm{PtCl}_{2}\left\{N, N^{\prime}-\mathrm{SeO}[\mathrm{NH}(\mathrm{t}-\mathrm{Bu})]_{2}\right\}\right](\mathbf{2})$ as a minor product. Attempts to prepare 2 by direct reaction of $\mathrm{SeOCl}_{2}$ with $\mathrm{Li}[\mathrm{NH}(\mathrm{t}-\mathrm{Bu})]$ in toluene followed by addition of $\mathrm{PtCl}_{2}$ produced cyclic $\mathrm{Se}_{4}[\mathrm{~N}(\mathrm{t}-\mathrm{Bu})]_{4}$ in solution $\left({ }^{77} \mathrm{Se} \mathrm{NMR}\right.$ spectrum) and a small amount of the complex $\left[\mathrm{PtCl}_{3}\left\{\mathrm{Se}, S e^{\prime}, S e^{\prime}-\mathrm{Se}_{4}[\mathrm{~N}(\mathrm{t}-\right.\right.$ $\left.\left.\mathrm{Bu})_{4}\right\}\right]\left[\mathrm{Pt}_{2} \mathrm{Cl}_{5}\left\{\mathrm{Se}, \mathrm{Se}, \mathrm{Se}^{\prime}-\mathrm{Se}_{3}[\mathrm{~N}(\mathrm{t}-\mathrm{Bu})]_{2}\right\}\right] \cdot 3 \mathrm{MeCN} \quad(3 \cdot 3 \mathrm{MeCN})$, which contains tridentate $\mathrm{Se}_{4}[\mathrm{~N}(\mathrm{t}-\mathrm{Bu})]_{4}$ in the cation and the novel, acyclic bridging ligand $[\mathrm{SeN}(\mathrm{t}-\mathrm{Bu}) \mathrm{SeN}(\mathrm{t}-\mathrm{Bu}) \mathrm{Se}]^{2-}$ in the anion. The reaction of $\mathrm{Se}[\mathrm{N}(\mathrm{t}-\mathrm{Bu})]_{2}$ with $\left[\mathrm{PtCl}_{2}(\mathrm{NCPh})_{2}\right]$ in $\mathrm{THF}$ produced the dinuclear complex $\left[\mathrm{Pt}_{2} \mathrm{Cl}_{6}\{\mathrm{SeN}(\mathrm{t}-\mathrm{Bu}) \mathrm{C}(\mathrm{Ph}) \mathrm{NH}\}_{2}\right] \cdot 2 \mathrm{C}_{4} \mathrm{H}_{8} \mathrm{O}(\mathbf{4} \cdot 2 \mathrm{THF})$ as the major product and only a few crystals of $\mathbf{1}$. The possible formation of $\mathrm{SeO}[\mathrm{NH}(\mathrm{t}-\mathrm{Bu})]_{2}$ or 2 by the reaction of $\mathrm{Se}[\mathrm{N}(\mathrm{t}-\mathrm{Bu})]_{2}$ or 1, respectively, with adventitious water and the pathway for the production of 4 were investigated through density functional theory calculations. The X-ray structures of $\mathbf{1}, \mathbf{2}$, 3.3MeCN, and 4.2THF have been determined.

Key words: platinum, selenium diimide, ${ }^{77}$ Se NMR spectroscopy, X-ray structures, DFT calculations 


\section{Introduction}

Chalcogen diimides show versatile coordination chemistry due to the availability of three potential donor sites and two formal $\pi$-bonds. ${ }^{1-6}$ The possible coordination modes are shown in Chart 1 and are dependent on the metal centre as well as the steric and electronic properties of the diimide ligands.

(Chart 1 here)

While $N, N^{\prime}$-chelation of sulfur diimides to both transition and main group metal centers is the most common mode of coordination, ${ }^{7-10}$ several complexes exhibit monodentate $N$-coordinated ligands; ${ }^{11-13}$ in addition, Resonance Raman spectra have indicated that the $\mathrm{M}(\mathrm{CO})_{5}$ fragment in the $\sigma(N)$-trigonal complex $\left[\mathrm{W}(\mathrm{CO})_{5}\left\{\mathrm{~S}(\mathrm{NMe})_{2}\right\}\right]$ undergoes a 1,3-shift. ${ }^{14,15}$ The unusual $\pi\left(N, N^{\prime}, S\right)$ coordination is found in $\left[\mathrm{Mn}_{2}(\mathrm{CO})_{6}\left\{\mathrm{~S}\left([\mathrm{~N}(\mathrm{t}-\mathrm{Bu})]_{2}\right\}\right] .^{9}\right.$

Most structurally characterized selenium diimide ligands are also monomeric and, like sulfur diimides, form $N, N^{\prime}$-chelated complexes. ${ }^{16-18}$ However, the bridging $N, N$ '-mode between two metal centres has also been observed. ${ }^{19,20}$ In addition to $\left[\operatorname{PdCl}_{2}\left\{N, N^{\prime}-\mathrm{Se}[\mathrm{N}(\mathrm{t}-\mathrm{Bu})]_{2}\right]\right.$, which has been prepared by the reaction of $\left[\mathrm{PdCl}_{2}(\mathrm{NCPh})_{2}\right]$ with one equivalent of $\mathrm{Se}[\mathrm{N}(\mathrm{t}-\mathrm{Bu})]_{2},{ }^{18}$ the reaction with two equivalents of $\mathrm{Se}[\mathrm{N}(\mathrm{t}-\mathrm{Bu})]_{2}$ affords $\left[\mathrm{PdCl}_{2}\left\{S e, S e e^{\prime}-\mathrm{Se}_{4}[\mathrm{~N}(\mathrm{t}-\mathrm{Bu})]_{3}\right\}\right]$ and $\left[\mathrm{PdCl}_{2}\left\{\mathrm{Se}, \mathrm{Se} e^{\prime} \mathrm{Se}_{4}[\mathrm{~N}(\mathrm{t}-\mathrm{Bu})]_{4}\right\}\right]$, which contain novel cyclic selenium imides.

The $[2+2]$ cyclodimerization of chalcogen diimides becomes more favorable for the heavier chalcogens. This process is strongly endothermic for sulfur diimides, approximately thermoneutral for selenium diimides, and strongly exothermic for tellurium diimides. ${ }^{21-23}$ 
Consistently, tellurium diimides occur only as thermally stable dimers $\mathrm{RNTe}(\mu-\mathrm{NR})_{2} \mathrm{TeNR},{ }^{24-26}$ which may act as $N, N^{\prime}$-chelating or bridging ligands coordinating to the metal centers through exocyclic nitrogen atoms, e.g. in complexes with $\mathrm{LiI} /\left[\mathrm{Li}(\mathrm{THF})_{2}\right]^{+},{ }^{27} \mathrm{HgCl}_{2},{ }^{28} \mathrm{CoCl}_{2},{ }^{17}$ and $\mathrm{M}\left(\mathrm{CF}_{3} \mathrm{SO}_{3}\right)(\mathrm{M}=\mathrm{Ag}, \mathrm{Cu}){ }^{29,30}$

We have recently observed that the complexation of $\mathrm{Se}[\mathrm{N}(\mathrm{t}-\mathrm{Bu})]_{2}$ with cadmium or mercury dichlorides results in cyclodimerization and formation of $\left[\mathrm{MCl}_{2}\left\{N, N^{\prime}-(\mathrm{t}-\mathrm{Bu}) \mathrm{NSe}[\mu-\mathrm{N}(\mathrm{t}-\right.\right.$ $\left.\left.\mathrm{Bu})]_{2} \mathrm{SeN}(\mathrm{t}-\mathrm{Bu})\right\}\right](\mathrm{M}=\mathrm{Cd}, \mathrm{Hg}),{ }^{31}$ which are isostructural with the mercury ${ }^{28}$ and cobalt ${ }^{17}$ complexes of tellurium diimide dimer. These complexes provided the first examples of the existence of dimeric selenium diimide. Furthermore, DFT calculations ${ }^{31}$ indicated that complexation of monomeric selenium diimides is favoured for group 10 metal dichlorides, as observed for $\mathrm{PdCl}_{2},{ }^{18}$ whereas coordination of dimeric selenium diimide ligands is preferred with group 12 metal dichlorides. ${ }^{31}$

In the light of our previous findings, ${ }^{18,31}$ we have now explored the reactions of $\mathrm{Se}[\mathrm{N}(\mathrm{t}-\mathrm{Bu})]_{2}$ with $\mathrm{PtCl}_{2}$ and $\left[\mathrm{PtCl}_{2}(\mathrm{NCPh})_{2}\right]$. The former produced the expected 1:1 adduct $\left[\mathrm{PtCl}_{2}\left\{N, N^{\prime}-\right.\right.$ $\left.\left.\mathrm{Se}[\mathrm{N}(\mathrm{t}-\mathrm{Bu})]_{2}\right\}\right]$ (1) and a small amount of $\left[\mathrm{PtCl}_{2}\left\{N, N^{\prime}-\mathrm{SeO}[\mathrm{NH}(\mathrm{t}-\mathrm{Bu})]_{2}\right\}\right]$ (2) containing the hitherto unknown selenoxide ligand $\mathrm{SeO}[\mathrm{NH}(\mathrm{t}-\mathrm{Bu})]_{2}$. Attempts to prepare 2 by reaction of $\mathrm{SeOCl}_{2}$ with $\mathrm{Li}[\mathrm{NH}(\mathrm{t}-\mathrm{Bu})]$ in toluene yielded cyclic selenium imides. The treatment of the resulting solution with $\mathrm{PtCl}_{2}$ afforded a few crystals of the ion pair $\left[\mathrm{PtCl}_{3}\left\{\mathrm{Se}, \mathrm{Se}\right.\right.$, $S e$,'-Se${ }_{4}[\mathrm{~N}(\mathrm{t}-$ $\left.\left.\mathrm{Bu})]_{4}\right\}\right]\left[\mathrm{Pt}_{2} \mathrm{Cl}_{5}\left\{\mathrm{Se}, \mathrm{Se}\right.\right.$,'Se' $\left.-\mathrm{Se}_{3}\left(\mathrm{~N}[(\mathrm{t}-\mathrm{Bu})]_{2}\right\}\right] \cdot 3 \mathrm{MeCN}(3 \cdot 3 \mathrm{MeCN})$. By contrast to the behaviour of $\left[\mathrm{PdCl}_{2}(\mathrm{NCPh})_{2}\right],{ }^{18}$ the treatment of $\mathrm{Se}[\mathrm{N}(\mathrm{t}-\mathrm{Bu})]_{2}$ with an equimolar amount of $\left[\mathrm{PtCl}_{2}(\mathrm{NCPh})_{2}\right]$ produced the complex $\left[\mathrm{Pt}_{2} \mathrm{Cl}_{6}\{\mathrm{SeN}(\mathrm{t}-\mathrm{Bu}) \mathrm{C}(\mathrm{Ph}) \mathrm{NH}\}_{2}\right] \cdot 2 \mathrm{C}_{4} \mathrm{H}_{8} \mathrm{O}(\mathbf{4} \cdot 2 \mathrm{THF})$.

We describe here the structural characterization of the complexes 1-4 (Chart 2). Reaction pathways for the unexpected formations of 2-4 are also proposed on the basis of DFT calculations (in the cases of $\mathbf{2}$ and $\mathbf{4}$ ). 
(Chart 2 here)

\section{Experimental section}

\section{General procedures}

All reactions and manipulations of air- and moisture-sensitive products were carried out under an inert atmosphere by using a standard drybox and Schlenk techniques. Tetrahydrofuran, diethylether, and toluene were dried by distillation over $\mathrm{Na} /$ benzophenone and acetonitrile was dried over $\mathrm{CaH}_{2}$ under an argon atmosphere prior to use. $\mathrm{SeCl}_{4}$ (Aldrich), $\mathrm{SeOCl}_{2}$ (Aldrich), $\mathrm{PtCl}_{2}$ (Johnson Matthey), n-BuLi (2.5 M in hexane, Aldrich) and benzonitrile (Fluka) were used as purchased. t-BuNH 2 (Aldrich) was distilled over $\mathrm{KOH}$ and stored over molecular sieves. $\mathrm{Se}[\mathrm{N}(\mathrm{t}-\mathrm{Bu})]_{2},{ }^{32}\left[\mathrm{PtCl}_{2}(\mathrm{NCPh})_{2}\right]{ }^{33}$ and $\mathrm{Li}[\mathrm{NH}(\mathrm{t}-\mathrm{Bu})]^{34}$ were synthesized by the literature procedure.

\section{NMR spectroscopy}

The ${ }^{13} \mathrm{C}\left\{{ }^{1} \mathrm{H}\right\},{ }^{14} \mathrm{~N},{ }^{77} \mathrm{Se}$, and ${ }^{195} \mathrm{Pt}$ NMR spectra were recorded unlocked on a Bruker Avance III 400 spectrometer operating at 100.61, 28.91, 76.31, and 86.02 MHz, respectively. The typical respective spectral widths were $24.04,28.99,113.64$, and $100.00 \mathrm{kHz}$, and the pulse widths were $14.30,12.00,16.75$, and $24.50 \mu \mathrm{s}$. The pulse delays for carbon, nitrogen, selenium, and platinum were 2.0, 0.01, 1.0, and $0.5 \mathrm{~s}$, respectively. The ${ }^{13} \mathrm{C}\left\{{ }^{1} \mathrm{H}\right\}$ NMR spectra were referenced to the solvent resonances and are reported relative to $\mathrm{Me}_{4} \mathrm{Si}$. Neat $\mathrm{CH}_{3} \mathrm{NO}_{2}$, a saturated $\mathrm{D}_{2} \mathrm{O}$ solution of selenium dioxide, and a $\mathrm{D}_{2} \mathrm{O}$ solution of $\mathrm{K}_{2}\left[\mathrm{PtCl}_{6}\right]$ were used as external standards for ${ }^{14} \mathrm{~N},{ }^{77} \mathrm{Se}$, and ${ }^{195} \mathrm{Pt}$ chemical shifts, respectively. The ${ }^{14} \mathrm{~N}$ and ${ }^{195} \mathrm{Pt}$ chemical shifts are reported relative to 
the external standards, and the ${ }^{77} \mathrm{Se}$ chemical shifts relative to neat $\mathrm{Me}_{2} \mathrm{Se}\left[\delta\left(\mathrm{Me}_{2} \mathrm{Se}\right)=\delta\left(\mathrm{SeO}_{2}\right)+\right.$ $1302.6] .35$

\section{Preparation of $\left[\operatorname{PtCl}_{2}\left\{N, N^{\prime}-\mathrm{Se}[\mathrm{N}(\mathrm{t}-\mathrm{Bu})]_{2}\right\}\right](1)$}

A slight excess of $\operatorname{Se}[\mathrm{N}(\mathrm{t}-\mathrm{Bu})]_{2}(0.279 \mathrm{~g}, 1.26 \mathrm{mmol})$, which was dissolved in toluene $(5 \mathrm{~mL})$, was added dropwise to a stirred brown slurry of $\mathrm{PtCl}_{2}(0.285 \mathrm{~g}, 1.07 \mathrm{mmol})$ in toluene $(15 \mathrm{~mL})$ at $-80{ }^{\circ} \mathrm{C}$. After $30 \mathrm{~min}$ at $-80{ }^{\circ} \mathrm{C}$, the reaction mixture was warmed slowly to room temperature and stirred overnight to give a reddish-brown solution and a reddish-brown precipitate. The solvent was removed under dynamic vacuum, and the solid residue was extracted with acetonitrile $(8 \times 10 \mathrm{~mL})$. The solvent was removed from the combined extracts under vacuum to give 1 as a reddish-brown solid $\left(0.380 \mathrm{~g}, 0.78 \mathrm{mmol}\right.$; yield $73 \%$ based on $\left.\mathrm{PtCl}_{2}\right)$ Anal. Calcd. for $\mathrm{C}_{8} \mathrm{H}_{18} \mathrm{Cl}_{2} \mathrm{~N}_{2} \mathrm{PtSe}(\mathbf{1})$ : C, 19.72; H, 3.72; N, $5.75 \%$. Found: C, 19.81; H, 3.60; N, $5.68 \%$. NMR: $\delta$ ${ }^{13} \mathrm{C}\left\{{ }^{1} \mathrm{H}\right\}\left(\mathrm{MeCN}, 25{ }^{\circ} \mathrm{C}\right): 56.63\left[-\mathrm{C}\left(\mathrm{CH}_{3}\right)_{3}\right]$ and $30.74 \mathrm{ppm}\left[-\mathrm{C}\left(\mathrm{CH}_{3}\right)_{3}\right] ; \delta^{77} \mathrm{Se}\left(\mathrm{MeCN}, 25{ }^{\circ} \mathrm{C}\right)$ : 1761, $\delta{ }^{195} \mathrm{Pt}\left(\mathrm{MeCN}, 25{ }^{\circ} \mathrm{C}\right):-1920$. Reddish-brown crystals of $\mathbf{1}$ were obtained by recrystallization from the acetonitrile solution at $-20{ }^{\circ} \mathrm{C}$ and were used for the determination of the crystal structure. Anal. Calcd. for $\mathrm{C}_{8} \mathrm{H}_{18} \mathrm{Cl}_{2} \mathrm{~N}_{2} \mathrm{PtSe}(\mathbf{1})$ : C, 19.72; H, 3.72; N, $5.75 \%$. Found: C, $19.88 ; \mathrm{H}, 3.78 ; \mathrm{N}, 5.52 \%$. A few yellow crystals of $\left[\mathrm{PtCl}_{2}\left\{N, N^{\prime}-\mathrm{SeO}[\mathrm{NH}(\mathrm{t}-\mathrm{Bu})]_{2}\right\}\right](2)$ were obtained in some batches during the crystallization of $\mathbf{1}$. Attempts to prepare complex $\mathbf{2}$ or the ligand $\mathrm{SeO}[\mathrm{NH}(\mathrm{t}-\mathrm{Bu})]_{2}$ are described in the Results and Discussion.

\section{Formation of $\left[\mathrm{Pt}_{2} \mathrm{Cl}_{6}\{\mathrm{SeN}(\mathrm{t}-\mathrm{Bu}) \mathrm{C}(\mathrm{Ph}) \mathrm{NH}\}_{2}\right] \cdot 2 \mathrm{C}_{4} \mathrm{H}_{8} \mathrm{O}(4 \cdot 2 \mathrm{THF})$}

A solution of $\mathrm{Se}[\mathrm{N}(\mathrm{t}-\mathrm{Bu})]_{2}(0.313 \mathrm{~g}, 1.42 \mathrm{mmol})$ in THF $(10 \mathrm{~mL})$ was added to a slurry of $\left[\mathrm{PtCl}_{2}(\mathrm{NCPh})_{2}\right](0.668 \mathrm{~g}, 1.42 \mathrm{mmol})$ in $\mathrm{THF}(20 \mathrm{~mL})$ at $-80{ }^{\circ} \mathrm{C}$. The reaction mixture was 
stirred for $15 \mathrm{~min}$ at $-80{ }^{\circ} \mathrm{C}$ and then allowed to warm overnight to room temperature. Unreacted $\left[\mathrm{PtCl}_{2}(\mathrm{NCPh})_{2}\right]$ was allowed to settle down and a dark red solution was decanted through a cannula. The solution was concentrated to a volume of $c a .15 \mathrm{~mL}$ under dynamic vacuum and cooled to $-20{ }^{\circ} \mathrm{C}$ to give yellow crystals of $4 \cdot 2 \mathrm{THF}$ and a few dark red crystals of 1 . Although the yellow crystals of $\mathbf{4} \cdot 2 \mathrm{THF}$ were predominant, it was not possible to separate the bulk product as a pure compound for overall yield or elemental analysis. However, a single crystal X-ray determination established the identity of this product.

\section{X-Ray crystallography}

Single-crystal X-ray diffraction data of $1,2,3 \cdot 3 \mathrm{MeCN}$, and $4 \cdot 2 \mathrm{THF}$ were collected on a Nonius Kappa CCD diffractometer using graphite-monochromated Mo $\mathrm{K}_{\alpha}$ radiation $(\lambda=0.71073$ $\AA$ ). Crystal data and the details of structure determinations are given in Table 1. All structures were solved by direct methods using SHELXS-2013 and refined using SHELXL-2013. ${ }^{36}$

(Table 1 here)

The complex $\left[\mathrm{PtCl}_{2}\left\{N, N^{\prime}-\mathrm{SeO}[\mathrm{NH}(\mathrm{t}-\mathrm{Bu})]_{2}\right\}\right]$ (2) contained a minor twin component in the crystal resulting in apparent crystallographic disorder. This disorder was resolved in terms of two alternative orientations of the complex. The site occupation factors were refined by constraining the anisotropic displacement parameters of the disordered pairs of atoms to be equal. The refined values of the s.o.f. were $0.9738(15)$ and $0.0262(15)$.

All methyl groups in the tert-butyl substituents of $3 \cdot 3 \mathrm{MeCN}$ can assume two different orientations. The consequent disorder was treated in the same way as above by constraining the anisotropic displacement parameters of all carbon atoms in the pairs of the disordered tert-butyl 
groups to be equal. The refined s.o.f. values of the two orientations of the three t-Bu groups are $0.77(2) / 0.23(2), 0.52(2) / 0.48(2)$, and 0.51(2)/0.49(2). The three solvent MeCN molecules lie on the symmetry element and also assume two different orientations. Because of symmetry, the s.o.f. values of each disordered pair is exactly 0.5 .

After the full-matrix least-squares refinement of the non-hydrogen atoms with anisotropic thermal parameters, the hydrogen atoms were placed in calculated positions in the $\mathrm{CH}_{3}$ groups $(\mathrm{C}-\mathrm{H}=0.98 \AA)$, in the $\mathrm{CH}_{2}$ groups $(\mathrm{C}-\mathrm{H}=0.99 \AA)$, and in the phenyl groups $(\mathrm{C}-\mathrm{H}=0.95 \AA)$. Upon the final refinement, they were riding with the carbon atom they were bonded to. For the complex 4 and for the more abundant orientation of the disordered pair in 2 , the $\mathrm{NH}$ hydrogens were found in the respective difference Fourier maps and refined isotropically. In case of the less-abundant orientation of $\mathbf{2}$, the $\mathrm{NH}$ hydrogen was placed in the calculated position $(\mathrm{N}-\mathrm{H}=$ $0.93 \AA$ ). The isotropic displacement parameters of the calculated hydrogen atoms were fixed at $1.2\left(\mathrm{CH}_{2}, \mathrm{NH}\right.$, phenyl groups) or $1.5\left(\mathrm{CH}_{3}\right)$ times to that of the corresponding carbon or nitrogen atom. The scattering factors for the neutral atoms were those incorporated with the program.

\section{Computational details}

All structures considered in this work were optimized using the ORCA program involving gradient techniques ${ }^{37}$ and employing a revPBE GGA functional ${ }^{38-40}$ and def2-TZVP ${ }^{41-44}$ basis

sets together with the RI approximation ${ }^{45}$ and Grimme's dispersion corrections. ${ }^{46,47}$ The fundamental frequencies were calculated to assess the nature of stationary points and to estimate the zero-point energy (ZPE) corrections and Gibbs reaction energies.

\section{Results and discussion}

Preparation and crystal structure of $\left[\operatorname{PtCl}_{2}\left\{N, N^{\prime}-\operatorname{Se}[\mathrm{N}(\mathrm{t}-\mathrm{Bu})]_{2}\right\}\right]$ (1) 
The reaction of a slight excess of $\mathrm{Se}[\mathrm{N}(\mathrm{t}-\mathrm{Bu})]_{2}$ and $\mathrm{PtCl}_{2}$ in toluene or THF afforded $\left[\mathrm{PtCl}_{2}\left\{N, N^{\prime}-\mathrm{Se}[\mathrm{N}(\mathrm{t}-\mathrm{Bu})]_{2}\right\}\right]$ (1). The crude product could be purified by extraction into acetonitrile followed by recrystallization and was isolated in $73 \%$ yield as reddish-brown crystals. The complex was characterized as a 1:1 adduct by elemental analysis, multinuclear NMR spectroscopy in acetonitrile solution, and X-ray crystallography. The ${ }^{13} \mathrm{C}\left\{{ }^{1} \mathrm{H}\right\}$ NMR spectrum of 1 showed the presence of equivalent tert-butyl groups [the chemical shifts are 56.63 ppm for $-\mathbf{C}\left(\mathrm{CH}_{3}\right)_{3}$ and $30.74 \mathrm{ppm}$ for $-\mathrm{C}\left(\mathrm{CH}_{3}\right)_{3}$ ] (intensity ratio 1:4), the ${ }^{77} \mathrm{Se}$ NMR spectrum displayed one resonance at $1761 \mathrm{ppm}$, and the ${ }^{195} \mathrm{Pt}$ NMR spectrum exhibited one resonance at $1920 \mathrm{ppm}$. The ${ }^{77} \mathrm{Se}$ NMR chemical shift for the palladium analogue is $1717 \mathrm{ppm} .{ }^{18}$

The molecular structure of $\mathbf{1}$ indicating the numbering of the atoms and selected bond parameters is shown in Fig. 1. Complex 1 is isostructural with the palladium analogue $\left[\mathrm{PdCl}_{2}\left\{N, N^{\prime}-\mathrm{Se}[\mathrm{N}(\mathrm{t}-\mathrm{Bu})]_{2}\right\}\right]{ }^{18}$ The platinum centre is coordinated by two chlorido ligands and two nitrogen atoms from the chelating selenium diimide ligand and exhibits an almost squareplanar coordination $\left[\Sigma \angle_{\mathrm{Pt}}=365.0^{\circ}\right]$. Upon complexation, the tert-butyl selenium diimide expectedly assumes the energetically least-favourable anti,anti-configuration, ${ }^{48}$ which is also observed in all other complexes containing the monomeric selenium diimide ligand. ${ }^{16-20}$

(Fig. 1 here)

The Se-N bond distances [1.743(6)-1.751(6) $\AA$ ] in $\mathbf{1}$ are similar to those reported earlier for the related complexes $\left[\mathrm{SnCl}_{4}\left\{N, N^{\prime}-\mathrm{Se}[\mathrm{N}(\mathrm{t}-\mathrm{Bu})]_{2}\right\}\right][1.710(3) \AA],{ }^{16}\left[\mathrm{PdCl}_{2}\left\{N, N^{\prime}-\mathrm{Se}[\mathrm{N}(\mathrm{t}-\mathrm{Bu})]_{2}\right\}\right]$ [1.731(4)-1.736(4) $\AA],{ }^{18}\left[\mathrm{Co}_{2}(\mu-\mathrm{Cl})_{3}\left\{N, N^{\prime}-\mathrm{Se}[\mathrm{N}(\mathrm{t}-\mathrm{Bu})]_{2}\right\}_{2}(\mathrm{THF})_{2}\right]-\left[\mathrm{CoCl}_{3}\left\{\mathrm{NH}_{2}(\mathrm{t}-\mathrm{Bu})\right\}\right] \cdot 1 \frac{1}{2} \mathrm{THF}$ $[1.716(5)-1.723(5)],{ }^{17}\left[\mathrm{Ag}_{2}\left\{\mu-N, N^{\prime}-\mathrm{Se}(\mathrm{NR})_{2}\right\}_{2}\right]\left(\mathrm{CF}_{3} \mathrm{SO}_{3}\right)_{2}(\mathrm{R}=\mathrm{t}-\mathrm{Bu}$, adamantyl) [1.712(4)- 
$1.749(7) \AA],{ }^{20}$ and $\left[\mathrm{Cu}_{2}\left\{\mu-N, N^{\prime}-\mathrm{Se}(\mathrm{NR})_{2}\right\}_{2}\right]\left(\mathrm{CF}_{3} \mathrm{SO}_{3}\right)_{2}(\mathrm{R}=\mathrm{t}-\mathrm{Bu}$, adamantyl) [1.708(4)-1.729(6) $\AA] .{ }^{20}$ The Pt-N bond lengths of 2.022(7) and 2.030(6) $\AA$ in $\mathbf{1}$ are close to the single bond lengths (the sum of covalent radii of platinum and nitrogen is $1.99 \AA^{49}$ ) and similar to those in related platinum(II) complexes $\left\{\right.$ cf. 1.997(12)-2.025(9) $\AA$ in $\left[\mathrm{PtCl}_{2}\{E-\mathrm{N}(\mathrm{H})=\mathrm{C}(\mathrm{SEt}) \mathrm{R}\}_{2}\right], \mathrm{R}=\mathrm{Me}, \mathrm{Et}$, $\left.\mathrm{CH}_{2} \mathrm{Ph}{ }^{50}\right\}$. The $\mathrm{Pt}-\mathrm{Cl}$ bond lengths of $\mathbf{1}$ also show typical single bond values [2.284(2)-2.297(2) $\AA$ ] (the sum of the covalent radii of platinum and chlorine is $2.28 \AA^{49}$ ). The corresponding bond lengths in $\left[\mathrm{PtCl}_{2}\{E-\mathrm{N}(\mathrm{H})=\mathrm{C}(\mathrm{SEt}) \mathrm{R}\}_{2}\right]$ are in the range $2.301(3)-2.314(4) \AA .{ }^{50}$

The crystal lattice of $\mathbf{1}$ is composed of discrete molecules that are linked together into a continuous three-dimensional network by Se $\cdots \mathrm{Cl}$ intermolecular contacts $[\mathrm{Se} 1 \cdots \mathrm{Cl} 1=3.5637(4)$ $\AA, \operatorname{Se} 1 \cdots \mathrm{Cl} 2=3.3943(5) \AA$ (the sum of van der Waals radii of selenium and chlorine is $3.81 \AA$ $\left.{ }^{49}\right)$ as also observed for $\left[\mathrm{PdCl}_{2}\left\{N, N^{\prime}-\mathrm{Se}[\mathrm{N}(\mathrm{t}-\mathrm{Bu})]_{2}\right\}\right]\left[\mathrm{Se} \cdot \cdots \mathrm{Cl}=3.270(14)-3.5058(14) \AA{ }^{18}{ }^{18} \mathrm{This}\right.$ continuous polymeric network (see Figure 1S in Supporting Information) may explain the low solubility of $\mathbf{1}$ in common organic solvents. Similar intermolecular contacts have been observed for the mercury and cobalt complexes of tellurium diimide dimer $\left[\mathrm{HgCl}_{2}\{(\mathrm{t}-\mathrm{Bu}) \mathrm{NTe}[\mu-\mathrm{N}(\mathrm{t}-\right.$ $\left.\mathrm{Bu})]_{2} \mathrm{TeN}(\mathrm{t}-\mathrm{Bu}\}\right]^{28}$ and $\left[\mathrm{CoCl}_{2}\left\{\left[(\mathrm{t}-\mathrm{Bu}) \mathrm{NTe}[\mu-\mathrm{N}(\mathrm{t}-\mathrm{Bu})]_{2} \mathrm{TeN}(\mathrm{t}-\mathrm{Bu})\right\}\right] .{ }^{17}\right.$

\section{Crystal structure of $\left[\operatorname{PtCl}_{2}\left\{N, N^{\prime}-\operatorname{SeO}[\mathrm{NH}(\mathrm{t}-\mathrm{Bu})]_{2}\right\}\right]$ (2)}

In some reaction batches, reddish-brown crystals of $\mathbf{1}$ were obtained together with a small amount of yellow crystals of $\left[\mathrm{PtCl}_{2}\left\{N, N^{\prime}-\mathrm{SeO}[\mathrm{NH}(\mathrm{t}-\mathrm{Bu})]_{2}\right\}\right]$ (2). The molecular structure of 2 together with the numbering of the atoms and the selected bond parameters is shown in Fig. 2 . The novel ligand $\mathrm{SeO}[\mathrm{NH}(\mathrm{t}-\mathrm{Bu})]_{2}$ is $N, N^{\prime}$-coordinated to the platinum centre, which has a square-planar coordination environment $\left[\Sigma \angle_{\mathrm{Pt}}=359.9^{\circ}\right]$ similar to that in 1 . The molecular framework adopts two orientations because of the apparent disorder, which is probably due to 
twinning, with the major and minor components (A and $\mathbf{B}$, respectively) showing site occupancy factors of $0.9738(15)$ and $0.0262(15)$, respectively. The square-planar coordination environments of platinum in these two disordered components form an angle of $85(1)^{\circ}$. Since the metrical values in the two disordered molecules are similar, the molecular and crystal structures are only discussed in terms of the major component.

(Fig. 2 here)

The Pt-Cl bond lengths of 2.318(4) and 2.320(4) $\AA$ and Pt-N bond lengths of 2.072(12) $\AA$ are quite normal. The Se-N bond lengths of 1.907(12) and 1.937(13) $\AA$ are consistent with the lengths of the endocyclic Se-N bonds in $(\mathrm{t}-\mathrm{Bu}) \mathrm{NSe}[\mu-\mathrm{N}(\mathrm{t}-\mathrm{Bu})]_{2} \mathrm{SeO}$ and $(\mathrm{t}-\mathrm{Bu}) \mathrm{NSe}[\mu-\mathrm{N}(\mathrm{t}-$ $\mathrm{Bu}]_{2} \mathrm{SO}_{2}$, which show a range of 1.930(4)-1.943(4) $\AA$ and 1.941(2)-1.958(2) $\AA$, respectively. ${ }^{51}$ The $\mathrm{Se}=\mathrm{O}$ bond length is $1.633(11) \AA$ and can be compared to the values of $1.621(2) \AA$ and $1.628(4) \AA$ in $\mathrm{OSe}[\mu-\mathrm{N}(\mathrm{t}-\mathrm{Bu})]_{2} \mathrm{SeO}^{52}$ and $(\mathrm{t}-\mathrm{Bu}) \mathrm{NSe}[\mu-\mathrm{N}(\mathrm{t}-\mathrm{Bu})]_{2} \mathrm{SeO}$, respectively. ${ }^{51}$ In contrast to $\mathbf{1}$, which shows a planar PtNSeN ring $\left[\Sigma \angle_{N}=359.8-360.0^{\circ}\right]$, that in 2 deviates significantly from planarity $\left[\Sigma \angle_{\mathrm{N}}=334.8-336.7^{\circ}\right]$.

The discrete complexes of $\mathbf{2}$ form dimeric units via weak $\mathrm{N}-\mathrm{H} \cdots \mathrm{Cl}$ hydrogen bonds of 2.285(5) and 2.306(5) $\AA$ (see Figure $2 \mathrm{~S}$ in Supporting Information). These dimeric units are further linked into a continuous polymeric network by the Se... O intermolecular contacts of $3.325(12) \AA$.

\section{Attempted preparation of $\mathrm{SeO}[\mathrm{NH}(\mathrm{t}-\mathrm{Bu})]_{2}$}


Since the ${ }^{77} \mathrm{Se}$ NMR spectrum of the commercial $\mathrm{SeCl}_{4}$ that was used for the synthesis of $\mathrm{Se}[\mathrm{N}(\mathrm{t}-\mathrm{Bu})]_{2}$ indicated that it contained ca. $5 \%$ of $\mathrm{SeOCl}_{2}$ (the ${ }^{77} \mathrm{Se} \mathrm{NMR}$ chemical shift is 1500 ppm ${ }^{53}$ ), we considered that the reaction of $\mathrm{SeOCl}_{2}$ with $\mathrm{t}-\mathrm{BuNH}_{2}$ is the source of $\mathrm{SeO}[\mathrm{NH}(\mathrm{t}-$ $\mathrm{Bu})]_{2}$ (Eq. 1) for the formation of 2.

$$
\mathrm{SeOCl}_{2}+4 \mathrm{t}-\mathrm{BuNH}_{2} \quad \rightarrow \quad \mathrm{SeO}[\mathrm{NH}(\mathrm{t}-\mathrm{Bu})]_{2}+2 \mathrm{t}-\mathrm{BuNH}{ }_{3} \mathrm{Cl}
$$

The ${ }^{77}$ Se NMR spectrum of the THF solution of the reaction mixture, after filtration, is shown in Fig. 3. The major resonance at $1245 \mathrm{ppm}$ can be assigned to $\mathrm{OSe}[\mu-\mathrm{N}(\mathrm{t}-\mathrm{Bu})]_{2} \mathrm{SeO}$ (cf. lit. value $1242 \mathrm{ppm}$ in $\mathrm{THF}^{22}$ ), which has previously been prepared by the reaction of $\mathrm{SeOCl}_{2}$ and t$\mathrm{BuNH}_{2}$ in diethyl ether. ${ }^{32}$ The resonance at $1656 \mathrm{ppm}$ is attributed to $\mathrm{Se}[\mathrm{N}(\mathrm{t}-\mathrm{Bu})]_{2}{ }^{54}$ There are two resonances at 1179 and $1155 \mathrm{ppm}$, either of which may be due to $\mathrm{SeO}[\mathrm{NH}(\mathrm{t}-\mathrm{Bu})]_{2}$. The ${ }^{77} \mathrm{Se}$ NMR chemical shift of 1136 ppm calculated at PBE0/def2-TZVPP level for SeO[NH(t-Bu) $]_{2}$ following a recently described theoretical approach ${ }^{55}$ suggests that the latter is more likely. The resonance at $1459 \mathrm{ppm}$ is at too low field to be due to $\mathrm{SeO}[\mathrm{NH}(\mathrm{t}-\mathrm{Bu})]_{2}$. Yellow crystals found in the precipitate after filtration were identified by unit cell determinations as $\mathrm{OSe}[\mu-\mathrm{N}(\mathrm{t}-$ $\mathrm{Bu})]_{2} \mathrm{SeO} .^{52}$

(Fig. 3 here)

We have also considered the possibility that $\mathrm{SeO}[\mathrm{NH}(\mathrm{t}-\mathrm{Bu})]_{2}$ is formed from $\mathrm{Se}[\mathrm{N}(\mathrm{t}-\mathrm{Bu})]_{2}$ by interaction with adventitious water during the preparation of 1 (Eq. 2): 


$$
\mathrm{Se}[\mathrm{N}(\mathrm{t}-\mathrm{Bu})]_{2}+\mathrm{H}_{2} \mathrm{O} \rightarrow \mathrm{SeO}[\mathrm{NH}(\mathrm{t}-\mathrm{Bu})]_{2}
$$

The reaction pathway based on DFT calculations at the revPBE/def2-TZVP level of theory is depicted in Fig. 4. The reaction begins with the interaction of one of the hydrogen atoms of water with a nitrogen atom of $\mathrm{Se}[\mathrm{N}(\mathrm{t}-\mathrm{Bu})]_{2}$ (transition state $\boldsymbol{T S \boldsymbol { 1 }}, \Delta G_{f}^{\mathrm{o}}=99 \mathrm{~kJ} \mathrm{~mol}^{-1}$;) leading to the cleavage of one $\mathrm{O}-\mathrm{H}$ bond in $\mathrm{H}_{2} \mathrm{O}$, followed by the immediate formation of a Se-O bond represented in the local minimum structure $\boldsymbol{B}\left(\Delta G_{f}^{\mathrm{o}}=9 \mathrm{~kJ} \mathrm{~mol}^{-1}\right)$. The second hydrogen transfer from the oxygen atom to a nitrogen atom proceeds via transition state $\boldsymbol{T S} 2\left(\Delta G_{f}^{\mathrm{o}}=66 \mathrm{~kJ} \mathrm{~mol}^{-1}\right)$ resulting in the product $\mathrm{SeO}[\mathrm{NH}(\mathrm{t}-\mathrm{Bu})]_{2}(\boldsymbol{C})$. The overall Gibbs energy of the reaction is calculated to be $-41 \mathrm{~kJ} \mathrm{~mol}^{-1}$.

Alternatively, 2 may be generated by the reaction of adventitious water with $\left[\mathrm{PtCl}_{2}\{N, N\right.$ '$\left.\left.\mathrm{Se}[\mathrm{N}(\mathrm{t}-\mathrm{Bu})]_{2}\right\}\right](\mathbf{1})$. However, this route is less likely than the direct reaction between $\mathrm{Se}[\mathrm{N}(\mathrm{t}-$ $\mathrm{Bu})]_{2}$ and $\mathrm{H}_{2} \mathrm{O}$, because the activation energies are significantly higher, and the total gain in Gibbs energy for the overall reaction is relatively small $\left(\Delta G_{f}^{0}=-4 \mathrm{~kJ} \mathrm{~mol}^{-1}\right)$ (see Fig. $5 \mathrm{~S}$ in Supporting Information).

(Fig. 4 here)

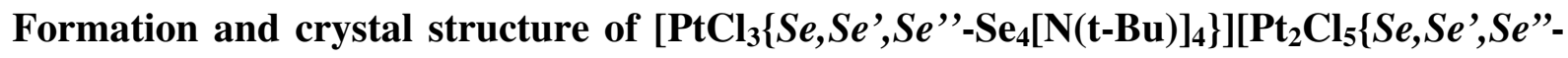 $\left.\mathrm{Se}_{3}\left[\mathrm{~N}(\mathrm{t}-\mathrm{Bu})_{2}\right\}\right] \cdot 3 \mathrm{MeCN}(3 \cdot 3 \mathrm{MeCN})$}

An attempt was also made to prepare $\left[\mathrm{PtCl}_{2}\left(N, N^{\prime}-\mathrm{SeO}[\mathrm{NH}(\mathrm{t}-\mathrm{Bu})]_{2}\right]\right.$ (2) by a two-stage reaction. The first stage involved the reaction of $\mathrm{SeOCl}_{2}$ and $\mathrm{Li}[\mathrm{NH}(\mathrm{t}-\mathrm{Bu})]$ in a molar ratio of 1:2 in toluene. The ${ }^{77} \mathrm{Se}$ NMR spectrum recorded from the filtrate of the reaction mixture showed the 
presence of $\mathrm{Se}[\mathrm{N}(\mathrm{t}-\mathrm{Bu})]_{2}(\delta 1654),{ }^{54} \mathrm{Se}_{3}[\mathrm{~N}(\mathrm{t}-\mathrm{Bu})]_{2}(\delta 1626$ and 1183$),{ }^{51}$ and $\mathrm{Se}_{3}[\mathrm{~N}(\mathrm{t}-\mathrm{Bu})]_{3}(\delta$ 1396) ${ }^{51}$ in addition to a strong resonance at $1451 \mathrm{ppm}$, which has been attributed to $\mathrm{Se}_{4}[\mathrm{~N}(\mathrm{t}-$ $\mathrm{Bu}]_{4}{ }^{55}$ In THF, this eight-membered ring shows a resonance at $1486 \mathrm{ppm} .{ }^{55}$

In the second stage, the resulting solution was treated with $\mathrm{PtCl}_{2}$. An acetonitrile extract of the crude product deposited a small amount of reddish-brown crystals of $\left[\mathrm{PtCl}_{3}\left\{\mathrm{Se}, \mathrm{Se}\right.\right.$,, $\mathrm{Se}$ ' $-\mathrm{Se}_{4}[\mathrm{~N}(\mathrm{t}-$ $\left.\left.\mathrm{Bu})]_{4}\right\}\right]\left[\mathrm{Pt}_{2} \mathrm{Cl}_{5}\left\{\mathrm{Se}, \mathrm{Se}\right.\right.$, $\left.\left.S e^{\prime}-\mathrm{Se}_{3}[\mathrm{~N}(\mathrm{t}-\mathrm{Bu})]_{2}\right\}\right] \cdot 3 \mathrm{MeCN}(3 \cdot 3 \mathrm{MeCN})$ together with pale yellow crystals of $\mathrm{t}-\mathrm{BuNH}_{3} \mathrm{Cl}$, identified by determination of the unit cell parameters. ${ }^{56}$

The molecular structure of $3 \cdot 3 \mathrm{MeCN}$ together with the numbering of the atoms and the selected bond parameters is shown in Fig. 5. The structure is composed of discrete mononuclear $\left[\mathrm{PtCl}_{3}\left\{\mathrm{Se}, \mathrm{Se} e^{\prime}, \mathrm{Se} e^{\prime \prime}-\mathrm{Se}_{4}[\mathrm{~N}(\mathrm{t}-\mathrm{Bu})]_{4}\right\}\right]^{+}$cations and dinuclear $\left[\mathrm{Pt}_{2} \mathrm{Cl}_{5}\left\{\mathrm{Se}, \mathrm{Se}, \mathrm{Se}^{\prime}-\mathrm{Se}_{3}[\mathrm{~N}(\mathrm{t}-\mathrm{Bu})]_{2}\right\}\right]^{-}$ anions. The asymmetric unit contains one half of atoms in both the cation and anion and the structure is completed by symmetry. In the solid state, the ions are paired together by $\mathrm{H} \cdots \mathrm{Cl}$ hydrogen bonds of $2.515(5)$ and 2.813(5) $\AA$; only the latter distance involving the more abundant orientation of the t-Bu-group in question is shown in Fig. 5. There is also a weak secondary bonding interaction of 3.220(6) A between the atoms Se3 and Cl31.

(Fig. 5 here)

The $\left[\mathrm{PtCl}_{3}\left\{S e, S e^{\prime}, S e{ }^{\prime}-\mathrm{Se}_{4}[\mathrm{~N}(\mathrm{t}-\mathrm{Bu})]_{2}\right\}\right]^{+}$cation consists of a puckered eight-membered cyclic selenium imide $\mathrm{Se}_{4}[\mathrm{~N}(\mathrm{t}-\mathrm{Bu})]_{4}$ ligand coordinating to platinum via three $\mathrm{Se}$ donors $[\mathrm{Pt}-\mathrm{Se}=$ 2.381(3)-2.4383(17) $\AA$ ]. The conformation of the ring is similar to that observed in $\left[\mathrm{PdCl}_{2}\left\{\mathrm{Se}, \mathrm{Se}^{\prime}-\mathrm{Se}_{4}[\mathrm{~N}(\mathrm{t}-\mathrm{Bu})]_{4}\right\}\right],{ }^{18}$ in which this ligand is bidentate $1,5-\mathrm{Se}, \mathrm{Se} e^{\prime}-\mathrm{Se}{ }_{4}[\mathrm{~N}(\mathrm{t}-\mathrm{Bu})]_{4}$ ligand; we note, however, that there is a weak contact of 3.1475(11) A between the palladium centre and the Se atom in the 3 position in this $\mathrm{Pd}$ complex. ${ }^{18}$ The free eight-membered ring 
$\mathrm{Se}_{4}(\mathrm{NMe})_{4}$ adopts a crown conformation. ${ }^{55}$ The platinum centre Pt1 shows a slightly distorted octahedral geometry. The Pt-Cl bond involving axial chlorine atom $[\mathrm{Pt} 1-\mathrm{Cl} 11=2.318(6) \AA]$ is slightly shorter than those involving equatorial chlorine atoms $[\mathrm{Pt} 1-\mathrm{Cl1} 2=2.366(4) \AA]$. The axial Pt1-Se1 bond of 2.381(3) $\AA$ is also shorter than the equatorial Pt1-Se2 bond of 2.4383(17) $\AA$.

The Se-N bond lengths of 1.811(12)-1.858(14) $\AA$ in the cation of $\mathbf{3}$ correspond to the typical single bond length of $1.87 \AA^{49}$ and are similar to those reported for $\left[\mathrm{PdCl}_{2}\left\{S e, S e e^{\prime}-\mathrm{Se}_{4}[\mathrm{~N}(\mathrm{t}-\right.\right.$ $\left.\left.\mathrm{Bu}]_{4}\right\}\right]\left[1.842(5)-1.886(4) \AA{ }^{18}\right.$ They are also consistent with the values found for the cyclic selenium imides $\mathrm{Se}_{4}(\mathrm{NMe})_{4}[1.823(10)-1.883(10) \AA],{ }^{55} \mathrm{Se}_{3}(\mathrm{NAd})_{2}$ [1.846(4)-1.892(4) $\AA$ ] ${ }^{22}$ $\mathrm{Se}_{3}[\mathrm{~N}(\mathrm{t}-\mathrm{Bu})]_{3}\left[1.825(4)-1.842(4) \AA{ }^{5}\right],{ }^{51} \mathrm{Se}_{6}[\mathrm{~N}(\mathrm{t}-\mathrm{Bu})]_{2}\left[1.830(4) \AA{ }^{5}\right],{ }^{57}$ and $\mathrm{Se}_{9}[\mathrm{~N}(\mathrm{t}-\mathrm{Bu})]_{6}[1.80(2)-$ 1.90(1) $\AA$ ].$^{57}$ The nitrogen atoms show a nearly planar bonding environment $[\Sigma \angle \mathrm{N}=351.7$ $359.6^{\circ}$, which, with the exception of $\mathrm{Se}_{3}(\mathrm{NAd})_{2},{ }^{22}$ is consistent with values reported for structurally characterized cyclic selenium imides. ${ }^{51,55,57}$

The most interesting feature of the structure of $\mathbf{3}$ is the presence of the bridging, acyclic $\left[\mathrm{Se}_{3}\{\mathrm{~N}(\mathrm{t}-\mathrm{Bu})\}_{2}\right]^{2-}$ ligand in the anion. This is the first example of this class of anionic chalcogennitrogen ligand, although the bridging acyclic nitrido ligands $\mathrm{S}_{3} \mathrm{~N}_{2}{ }^{2-}{ }^{58-60}$ and $\mathrm{SeS}_{2} \mathrm{~N}_{2}{ }^{2-61}$ bear a close relationship to this imido-selenium dianion. The platinum centres in the $\operatorname{Pt}_{2} \mathrm{Cl}_{5}\{\mathrm{Se}, \mathrm{Se}$ ',Se”$\left.\left.\mathrm{Se}_{3}[\mathrm{~N}(\mathrm{t}-\mathrm{Bu})]_{2}\right\}\right]^{-}$anion are in different oxidation states $\mathrm{Pt}^{\mathrm{IV}}$ and $\mathrm{Pt}^{\mathrm{II}}$. Similar dinuclear complexes involving mixed oxidation states are also exemplified by $\left(\mathrm{Et}_{4} \mathrm{~N}\right)\left[\mathrm{Cl}_{2} \mathrm{Pt}\{\mu-\mathrm{Cl}(\mathrm{NO})\} \mathrm{PtCl}_{3}(\mathrm{NO})\right]$, $\left[\left(\mathrm{Et}_{3} \mathrm{P}\right)_{2} \mathrm{Pt}(\mu-\mathrm{SiH}-\mathrm{Ph})_{2} \mathrm{Pt}\left(\mathrm{SiH}_{2}\right)_{2}\left(\mathrm{PEt}_{3}\right)_{2}\right],{ }^{63} \quad\left[\mathrm{Pt}\left\{\mathrm{PtMe}_{3}\left(\mathrm{SCH}_{2} \mathrm{CH}_{2} \mathrm{NMe}_{2}\right)_{2}\right\}_{2}\right],{ }^{64} \quad$ and $\left[\left\{\left(\mathrm{Me}_{3} \mathrm{P}\right)_{2} \mathrm{Pt}\right\}_{3} \mathrm{Pt}(\mathrm{OH})_{6}\right]\left(\mathrm{NO}_{3}\right)_{4} \cdot{ }^{65}$

The platinum center $\mathrm{Pt}^{\mathrm{IV}}$ in the $\left[\mathrm{Pt}_{2} \mathrm{Cl}_{5}\left\{\mathrm{Se}, \mathrm{Se} e^{\prime}, \mathrm{Se}{ }^{\prime}-\mathrm{Se}_{3}[\mathrm{~N}(\mathrm{t}-\mathrm{Bu})]_{2}\right\}\right]^{-}$anion exhibits a distorted octahedral coordination sphere, whereas the coordination geometry at the platinum center $\mathrm{Pt}^{\mathrm{II}}{ }^{\text {is }}$ 
square-planar. The axial Pt2-Se5 bond of 2.399(2) $\AA$ is shorter than the equatorial Pt2-Se4 bond of 2.4240(17) $\AA$, as also found for Pt1 in the cation. The corresponding Pt-Cl bonds, however, show almost equal lengths [2.365(6) and 2.362(5) $\AA$ ]. The Pt3-Se4 bond of 2.3617(17) $\AA$ and the Pt3-Cl31 bonds of 2.342(4) $\AA$ involving the square-planar centre $\mathrm{Pt} 3{ }^{\mathrm{II}}$ are shorter than those of octahedral Pt(IV) centres Pt1 and Pt2. As in the cation, the Se-N bond distances of 1.840(14)$1.880(13) \AA$ in the $\mathrm{Se}_{3}[\mathrm{~N}(\mathrm{t}-\mathrm{Bu})]_{2}{ }^{2-}$ ligand of the anion are close to the predicted Se-N single bond length. The bonding environment at the nitrogen atoms is close to planar $\left[\Sigma \angle \mathrm{N}=356.5^{\circ}\right]$. In the solid state, the ion pairs are linked together by a complicated three-dimensional $\mathrm{H} \cdots \mathrm{Cl}$ hydrogen bonding network, as shown in Fig. 3S in Supporting Information.

Since the ${ }^{77} \mathrm{Se}$ NMR spectrum shows that the toluene solution from the reaction of $\mathrm{Li}[\mathrm{NH}(\mathrm{t}-$ $\mathrm{Bu})]$ and $\mathrm{SeOCl}_{2}$ contains $\mathrm{Se}_{4}[\mathrm{~N}(\mathrm{t}-\mathrm{Bu})]_{4}, \mathrm{Se}_{3}[\mathrm{~N}(\mathrm{t}-\mathrm{Bu})]_{3}$, and $\mathrm{Se}_{3}[\mathrm{~N}(\mathrm{t}-\mathrm{Bu})]_{2}$, in addition to $\mathrm{Se}[\mathrm{N}(\mathrm{t}-$ $\mathrm{Bu})]_{2}$, it is likely that imidoselenium chlorides $\mathrm{ClSe}[\mathrm{N}(\mathrm{t}-\mathrm{Bu}) \mathrm{Se}]_{n} \mathrm{Cl}(n=1,2)$ are also present in the solution. ${ }^{51,66}$ Consequently, the formation of $\mathbf{3}$ can be envisaged to involve a redox process between $\mathrm{PtCl}_{2}$ and $\mathrm{ClSe}\left[\mathrm{N}(\mathrm{t}-\mathrm{Bu}) \mathrm{Se}_{2} \mathrm{Cl}\right.$ concomitant with the formation of a complex of $\mathrm{Se}_{4}[\mathrm{~N}(\mathrm{t}-$ $\mathrm{Bu})]_{4}$ with $\mathrm{PtCl}_{2}$ in the presence of $\mathrm{Cl}^{-}$ions (see Scheme 1).

(Scheme 1 here) 


\section{Formation of $\left[\mathrm{Pt}_{2} \mathrm{Cl}_{6}\{\mathrm{SeN}(\mathrm{t}-\mathrm{Bu}) \mathrm{C}(\mathrm{Ph}) \mathrm{NH}\}_{2}\right](4)$}

By contrast to the reaction of $\mathrm{Se}[\mathrm{N}(\mathrm{t}-\mathrm{Bu})]_{2}$ with $\left[\mathrm{PdCl}_{2}(\mathrm{NCPh})_{2}\right],{ }^{18}$ the corresponding reaction with $\left[\mathrm{PtCl}_{2}(\mathrm{NCPh})_{2}\right]$ in $\mathrm{THF}$ produced a complex mixture of selenium-nitrogen compounds, including $\mathrm{Se}_{3}[\mathrm{~N}(\mathrm{t}-\mathrm{Bu})]_{3}, \mathrm{Se}_{4}[\mathrm{~N}(\mathrm{t}-\mathrm{Bu})]_{4}$, and $\mathrm{OSe}[\mu-(\mathrm{t}-\mathrm{Bu})]_{2} \mathrm{SeO}$, as indicated by the ${ }^{77} \mathrm{Se} \mathrm{NMR}$ spectra in Fig. 6. Only a small amount of $\mathbf{1}$ in the form of dark red crystals was obtained (see Experimental Section). It can also be seen from Fig. 6(b) that a large amount of $\mathrm{Se}[\mathrm{N}(\mathrm{t}-\mathrm{Bu})]_{2}$ remained unreacted when the molar ratio was changed from 1:1 to $2: 1$.

(Fig. 6 here)

Upon standing of the reaction solution overnight at $-20{ }^{\circ} \mathrm{C}$, yellow crystals of the dinuclear $\left[\mathrm{Pt}_{2} \mathrm{Cl}_{6}\{\mathrm{SeN}(\mathrm{t}-\mathrm{Bu}) \mathrm{C}(\mathrm{Ph}) \mathrm{NH}\}_{2}\right] 4 \cdot 2 \mathrm{THF}$ and a small amount of dark red crystals of mononuclear 1 could be obtained. The molecular structure of $4 \cdot 2 \mathrm{THF}$ together with the numbering of atoms and selected bond parameters is shown in Fig. 7. The asymmetric unit contains one half of the atoms in the complex and the full molecular structure is completed by symmetry. The structure consists of two chelating and bridging $\mathrm{N}(\mathrm{H}) \mathrm{C}(\mathrm{Ph}) \mathrm{N}(\mathrm{t}-\mathrm{Bu}) \mathrm{Se}$ ligands, which link two $\mathrm{PtCl}_{3}$ fragments into a dinuclear complex. Both platinum(IV) centers exhibit an octahedral coordination sphere. The Pt-Se bond distances are 2.3790(7) $\AA$ and 2.4482(8) $\AA$ \{cf. 2.384(2)$2.423(2) \AA]$ in the dimeric $\left.\left[\mathrm{PtCl}_{2}\left(\mathrm{Se}_{2} \mathrm{C}_{7} \mathrm{H}_{5}\right)\left(\mathrm{C}_{7} \mathrm{H}_{5}\right)\right]_{2}\right\} .{ }^{67}$ The Pt-Cl bonds trans to selenium $[2.3518(15)$ and $2.3598(16) \AA]$ are slightly longer than those trans to the nitrogen atom

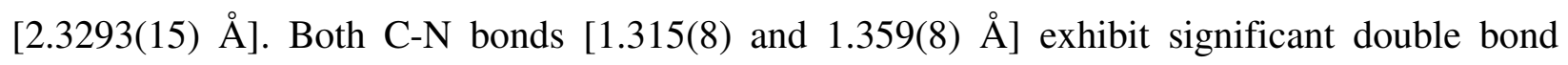
character $\left[\mathrm{C}-\mathrm{N}=1.47 \AA, \mathrm{C}=\mathrm{N}=1.30 \AA^{49}\right]$ indicating delocalization of the $\pi$-electron density. Consistently, the bonding arrangements around the $\mathrm{C} 1, \mathrm{~N} 1$ and $\mathrm{N} 2$ atoms are all nearly planar 
$\left[\Sigma \angle \mathrm{C}=359.9^{\circ}\right.$ and $\left.\Sigma \angle \mathrm{N}=358.9-360.0^{\circ}\right]$. The Se1-N2 bond length of 1.865(5) $\AA$ indicates a single bond. ${ }^{49}$ The combined structural data suggest that the bridging ligand can be formulated as $\mathrm{N}(\mathrm{H}){ }_{-\mathrm{C}} \mathrm{C}(\mathrm{Ph}){ }^{\cdots} \mathrm{N}(\mathrm{t}-\mathrm{Bu})-\mathrm{Se}^{-}$. The packing arrangement is shown in Fig. 4S in Supporting Information.

The reaction pathway to this ligand merits further consideration in the light of the findings of Belluco et al., ${ }^{68}$ who have demonstrated that the benzonitrile ligands in $\left[\mathrm{PtCl}_{2}(\mathrm{NCPh})_{2}\right]$ react with primary or secondary amines. The ${ }^{195} \mathrm{Pt} \mathrm{NMR}$ spectrum of $\left[\mathrm{PtCl}_{2}(\mathrm{NCPh})_{2}\right]$ shows two resonances at -2295 and $-2387 \mathrm{ppm}$ of approximately equal intensities attributable to cis- and trans-isomers, respectively. Consistently, the revPBE/def2-TZVP calculations also show that the difference in Gibbs energies of cis- and trans- $\left[\mathrm{PtCl}_{2}(\mathrm{NCPh})_{2}\right]$ is only $11 \mathrm{~kJ} \mathrm{~mol}^{-1}$ with the transisomer being more stable. As proposed in Scheme 2 the first step in the formation of 4 is the reaction of $\mathrm{t}-\mathrm{BuNH}_{2}$, with a $\mathrm{C} \equiv \mathrm{N}$ triple bond in cis- $\left[\mathrm{PtCl}_{2}(\mathrm{NCPh})_{2}\right]$, which gives cis$\left[\mathrm{PtCl}_{2}(\mathrm{NCPh})\{\mathrm{N}(\mathrm{H})=\mathrm{C}(\mathrm{Ph})-\mathrm{N}(\mathrm{t}-\mathrm{Bu})(\mathrm{H})\}\right]$. The reaction with trans-[PtCl$\left.{ }_{2}(\mathrm{NCPh})_{2}\right]$ results in the formation of the trans-isomer. The ${ }^{77} \mathrm{Se}$ NMR spectra of some reaction mixtures showed the presence of $\mathrm{SeCl}_{2}$ at $1828 \mathrm{ppm},{ }^{69}$ presumably formed from $\mathrm{SeCl}_{4}$ via the redox transformation depicted in eq (3). In support of this suggestion, the ${ }^{14} \mathrm{~N}$ NMR spectra of the solutions demonstrated the formation of $(\mathrm{t}-\mathrm{Bu}) \mathrm{N}=\mathrm{N}(\mathrm{t}-\mathrm{Bu})(151 \mathrm{ppm}) .^{51}$

$$
\mathrm{SeCl}_{4}+3 \mathrm{t}-\mathrm{BuNH}_{2} \quad \rightarrow \quad \mathrm{SeCl}_{2}+1 / 2(\mathrm{t}-\mathrm{Bu}) \mathrm{N}=\mathrm{N}(\mathrm{t}-\mathrm{Bu})+2 \mathrm{t}-\mathrm{BuNH}_{3} \mathrm{Cl}(\mathrm{s})
$$

The reaction of $\mathrm{SeCl}_{2}$ with the $\mathrm{NH}$ group of $\left[\mathrm{PtCl}_{2}(\mathrm{NCPh})\{\mathrm{N}(\mathrm{H})=\mathrm{C}(\mathrm{Ph})-\mathrm{N}(\mathrm{t}-\mathrm{Bu})(\mathrm{H})\}\right]$ will produce the Se-N bond in the intermediate $\left[\mathrm{PtCl}_{2}(\mathrm{NCPh})\{\mathrm{N}(\mathrm{H})=\mathrm{C}(\mathrm{Ph})-\mathrm{N}(\mathrm{t}-\mathrm{Bu})(\mathrm{SeCl})\}\right]$ and a precipitate of $\mathrm{t}-\mathrm{BuNH}_{3} \mathrm{Cl}(\mathrm{s})$, which is the driving force of the reaction (see Scheme 2). The 
subsequent oxidative addition of the Se- $\mathrm{Cl}$ bond of the ligand to the platinum center, and the dimerization of the monomer so formed subsequently generates the observed dinuclear complex 4.

(Scheme 2 here)

We have investigated the oxidative-addition step and the subsequent dimerization by using DFT techniques at revPBE/def2-TZVP level of theory. The reactions of both cis- and trans$\left[\mathrm{PtCl}_{2}(\mathrm{NCPh})\{\mathrm{N}(\mathrm{H})=\mathrm{C}(\mathrm{Ph})-\mathrm{N}(\mathrm{t}-\mathrm{Bu})(\mathrm{SeCl})\}\right](\boldsymbol{A})$ were considered separately. The energy profile of the reaction involving the $c i s$-isomer of $\boldsymbol{A}$ is shown in Fig. 8. The selenium atom in $\boldsymbol{A}$ is first attached to the platinum atom via the transition state TS1 forming an intermediate $\boldsymbol{B}$, after which the chlorine atom is transferred from selenium to platinum via the transition state TS2 with the formation of the $f a c$ isomer of the six coordinate platinum(IV) complex $\boldsymbol{C}$. The activation energies for the two transition states TS1 and TS2 are 59 and $16 \mathrm{~kJ} \mathrm{~mol}^{-1}$, respectively. The relatively low activation energy of $\mathbf{T S 3}\left(24 \mathrm{~kJ} \mathrm{~mol}^{-1}\right)$ indicates the ease with which the remaining PhCN ligand can leave the six-coordinate platinum centre. The virtually simultaneous dimerization of the $\left[\mathrm{PtCl}_{3}\{\mathrm{~N}(\mathrm{H}) \mathrm{C}(\mathrm{Ph}) \mathrm{N}(\mathrm{t}-\mathrm{Bu}) \mathrm{Se}\}\right]$ monomer structure shows no activation barrier and leads to the final dinuclear complex 4. The total Gibbs energy change in the oxidation and dimerization process is very exothermic $\left(\Delta \mathrm{G}=-151 \mathrm{~kJ} \mathrm{~mol}^{-1}\right)$.

(Fig. 8 here) 
The oxidative addition starting from trans- $\left[\mathrm{PtCl}_{2}(\mathrm{NCPh})\{\mathrm{N}(\mathrm{H})=\mathrm{C}(\mathrm{Ph})-\mathrm{N}(\mathrm{t}-\mathrm{Bu})(\mathrm{SeCl})\}\right]$ yields the mer-arrangement of chlorido ligands in the intermediate $\boldsymbol{C}$. The mer-isomer must undergo isomerization to the fac-isomer for the dimerization to lead to the observed product 4. However, the energy barrier to isomerize the mer-isomer into the fac-isomer is very high rendering this route unlikely. It can therefore be inferred that only cis- $\left[\mathrm{PtCl}_{2}(\mathrm{NCPh})_{2}\right]$ will result in the formation of the dinuclear complex 4. This conclusion finds qualitative experimental support from ${ }^{195} \mathrm{Pt}$ spectroscopy. The isomeric composition of the unreacted $\left[\mathrm{PtCl}_{2}(\mathrm{NCPh})_{2}\right]$ in the final reaction solution is ca. 10 mol-\% cis-isomer and 90 mol-\% trans-isomer (cf. the initial approximately equal isomeric composition) indicating that during the reaction the cis-isomer has been consumed in preference to the trans-isomer.

A similar difference in the behaviour between palladium and platinum has been reported by Bates et $a l .{ }^{67}$ Whereas the reaction of cyclohepteno-1,4-diselenin with $\left[\mathrm{PdCl}_{2}(\mathrm{NCPh})_{2}\right]$ leads to exchange of two benzonitrile ligands by two diselenin ligands to give a mononuclear trans complex coordinating via selenium, the corresponding reaction with $\left[\mathrm{PtCl}_{2}(\mathrm{NCPh})_{2}\right]$ results in the oxidation of platinum(II) to six-coordinate platinum(IV) with the formation of a dinuclear complex, which shows structural features similar to those in 4 (see Scheme 3).

(Scheme 3 here)

\section{Conclusions}

The reaction of $\mathrm{Se}[\mathrm{N}(\mathrm{t}-\mathrm{Bu})]_{2}$ and $\mathrm{PtCl}_{2}$ affords a complex of the monomeric selenium diimide $\left[\mathrm{PtCl}_{2}\left\{N, N^{\prime}-\mathrm{Se}[\mathrm{N}(\mathrm{t}-\mathrm{Bu})]_{2}\right\}\right](\mathbf{1})$, as predicted by theoretical calculations. ${ }^{31}$ The structure of the 
minor product $\left[\mathrm{PtCl}_{2}\left\{N, N^{\prime}-\mathrm{SeO}[\mathrm{NH}(\mathrm{t}-\mathrm{Bu})]_{2}\right\}\right]$ (2), which contains the hitherto unknown $\mathrm{SeO}[\mathrm{NH}(\mathrm{t}-\mathrm{Bu})]_{2}$ ligand, was also determined. DFT calculations showed that the reaction of $\mathrm{Se}[\mathrm{N}(\mathrm{t}-\mathrm{Bu})]_{2}$ with adventitious water is a plausible source of this ligand. The structurally intriguing ion pair $\left[\mathrm{PtCl}_{3}\left\{S e, S e^{\prime}, S e ”-\mathrm{Se}_{4}[\mathrm{~N}(\mathrm{t}-\mathrm{Bu})]_{4}\right\}\right]\left[\mathrm{Pt}_{2} \mathrm{Cl}_{5}\left\{S e, S e,, S e ”-\mathrm{Se}_{3}[\mathrm{~N}(\mathrm{t}-\mathrm{Bu})]_{2}\right\}\right] \cdot 3 \mathrm{MeCN}$ $(3 \cdot 3 \mathrm{MeCN})$ was also characterized as a minor product in attempts to generate 2 . The anion in $\mathbf{3}$ embodies the acyclic $\left[\mathrm{Se}_{3}\left[\mathrm{~N}(\mathrm{t}-\mathrm{Bu})_{2}\right]^{2-}\right.$ dianion as a bridging ligand, which is likely formed by a redox process involving $\mathrm{ClSe}\left[\mathrm{N}(\mathrm{t}-\mathrm{Bu}) \mathrm{Se}_{2} \mathrm{Cl}, \mathrm{Se}_{4}[\mathrm{~N}(\mathrm{t}-\mathrm{Bu})]_{4}\right.$, and $\mathrm{PtCl}_{2}$. This finding suggests a rich coordination chemistry for complexes of new Se-N ligands generated from imidoselenium chlorides $^{51,66}$ and metal halides.

The reaction of $\left[\mathrm{PtCl}_{2}(\mathrm{NCPh})_{2}\right]$ and $\mathrm{Se}[\mathrm{N}(\mathrm{t}-\mathrm{Bu})]_{2}$ produced the dinuclear complex $\left[\mathrm{Pt}_{2} \mathrm{Cl}_{6}\{\mathrm{SeN}(\mathrm{t}-\mathrm{Bu}) \mathrm{C}(\mathrm{Ph}) \mathrm{NH}\}_{2}\right] \cdot 2 \mathrm{C}_{4} \mathrm{H}_{8} \mathrm{O}(4 \cdot 2 \mathrm{THF})$ as the main product and only a small amount of $\mathbf{1}$. The formation of $\mathbf{4}$ via the initial addition of $\mathrm{t}-\mathrm{BuNH}_{2}$ to the $\mathrm{C} \equiv \mathrm{N}$ triple bond of a platinumactivated $\mathrm{PhCN}$ ligand in cis-[ $\left[\mathrm{PtCl}_{2}(\mathrm{NCPh})_{2}\right]$, and subsequent reaction with $\mathrm{SeCl}_{2}$, is suggested. DFT calculations of the energy profile for the proposed reaction pathway indicated that only the cis-isomer of $\left[\mathrm{PtCl}_{2}(\mathrm{NCPh})_{2}\right]$ leads to the dinuclear complex 4.

\section{Supplementary Material}

Supplementary material (packing of complexes in $\mathbf{1}, \mathbf{2}, \mathbf{3} \cdot 3 \mathrm{MeCN}$, and $\mathbf{4} \cdot 2 \mathrm{THF}$, the Gibbs energy profile of the reaction of $\left[\mathrm{PtCl}_{2}\left\{N, N^{\prime}-\mathrm{Se}[\mathrm{N}(\mathrm{t}-\mathrm{Bu})]_{2}\right\}\right]$ (1) with water is available with the article through the journal Web site at http://nrcresearchpress.com/doi/suppl/10.1139/cjc-2015xxxx. CCDC 1418459-1418462 contain the X-ray data for $\mathbf{1}, \mathbf{2}, \mathbf{3} \cdot 3 \mathrm{MeCN}$, and $\mathbf{4} \cdot 2 \mathrm{THF}$ in CIF format. These data can be obtained, free of charge, via http://www.ccdc.cam.ac.uk/products/csd/request (or from the Cambridge Crystallographic Data 
Centre,12 Union Road, Cambridge CB2 1E2, UK; fax: +44 122333603 or e-mail:

deposit@ccdc.cam.ac.uk

\section{Acknowledgements}

Financial support from Academy of Finland (J. M. R.), Finnish Cultural Foundation (A.J.K., M.R.), Magnus Ehrnrooth Foundation (A.J.K.), and and the Natural Sciences and Engineering Research Council (NSERC, Canada) (T. C.) is gratefully acknowledged. We are also grateful to Finnish CSC - IT Center for Science Ltd for their generous provision of computational resources.

\section{References}

(1) Hill, A. F. Adv. Organomet. Chem. 1994, 36, 159. doi:10.1016/S0065-3055(08)60391-3.

(2) Chivers, T. A Guide to Chalcogen-Nitrogen Chemistry, World Scientific Publishing Co. Pte. Ltd: Singapore, 2005.

(3) Chivers, T.; Laitinen, R. S., Chalcogen-Nitrogen Chemistry, in Devillanova, F. (ed.), Handbook of Chalcogen Chemistry, New Perspectives in Sulfur, Selenium and Tellurium, RSC Press: Cambridge, 2007, p. 223. doi: 10.1039/9781847557575-00223.

(4) Laitinen, R. S.; Oilunkaniemi, R.; Chivers, T., Synthesis, Structures, Bonding, and Reactions of Imido-Selenium and -Tellurium Compounds, in Woollins, J. D.; Laitinen, R. S. (eds.), Selenium and Tellurium Chemistry: From Small Molecules to Biomolecules and Materials, Springer Verlag, Berlin, 2011, p. 103. doi: 10.1007/978-3-642-20699-3_5.

(5) Chivers, T.; Laitinen, R. S., Recent Developments in Chalcogen-Nitrogen Chemistry, in Devillanova, F.; du Mont, W.-W. (eds.), Handbook of Chalcogen Chemistry: New 
Perspectives in Sulfur, Selenium and Tellurium, RSC Publishing: Cambridge, 2013, p. 191. doi: 10.1039/9781849737456-00191.

(6) Chivers, T.; Laitinen, R. S. Chem. Soc. Rev. 2015, 44, 1725. doi: 10.1039/C4CS00434E.

(7) Meij, R.; Olie, K. Cryst. Struct. Commun. 1975, 4, 515.

(8) Roesky, H. W.; Schmidt, H.-G.; Noltemeyer, N.; Sheldrick, G. M. Chem.Ber. 1983, 116, 1411. doi: 10.1002/cber.19831160416.

(9) Mahabiersing, C.; de Lange, W. G. J.; Goubitz, K.; Stufkens, D. J. J. Organomet. Chem. 1993, 461, 127. doi:10.1016/0022-328X(93)83284-3.

(10) Kaleta, K.; Ruhmann, M.; Theilmann, O.; Roy, S.; Beweries, T.; Arndt, P.; Villinger, A.; Jemmis, E. D.; Schulz, A.; Rosenthal, U. Eur. J. Inorg. Chem. 2012, 611. doi: 10.1002/ejic.201101188.

(11) Kops, R. T.; van Aken, E.; Schenk, H. Acta Crystallogr., Sect. B 1973, 29, 913. doi: 10.1107/S0567740873003559.

(12) Limmert, M.; Lorenz, I.-P.; Neubauer, J.; Nöth, H.; Habereder, T. Eur. J. Inorg. Chem. 2001, 1593. doi: 10.1002/1099-0682(200106)2001:6<1593::AID-EJIC1593>3.0.CO;2-P.

(13) Hubrich, C.; Schulz, A.; Villinger, A. Z. Anorg. Allg. Chem. 2007, 633, 2362. doi: 10.1002/zaac.200700245.

(14) Meij, R.; Kuyper, J.; Stufkens, D. J.; Vrieze, K. J. Organomet. Chem. 1976, 110, 219. doi:10.1016/S0022-328X(00)89693-X.

(15) Meij, R.; Kaandorp, T. A. M.; Stufkens, D. J.; Vrieze, K. J. Organomet. Chem. 1977, 128, 203. doi:10.1016/S0022-328X(00)90125-6.

(16) Gindl, J.; Björgvinsson, M.; Roesky, H. W.; Freire-Erdbrügger, C.; Sheldrick, G. M. J. Chem. Soc., Dalton Trans. 1993, 811. doi: 10.1039/DT9930000811. 
(17) Risto, M.; Konu, J.; Oilunkaniemi, R.; Laitinen, R. S.; Chivers, T. Polyhedron, 2010, 29, 871. doi:10.1016/j.poly.2009.10.006.

(18) Risto, M.; Eironen, A.; Männistö, E.; Oilunkaniemi, R.; Laitinen, R. S.; Chivers, T. Dalton Trans. 2009, 8473. doi: 10.1039/B910049K.

(19) Wrackmeyer, B.; Köhler, C.; Milius, W.; Herberhold, M. Z. Anorg. Allg. Chem. 1995, 621, 1625. doi: 10.1002/zaac.19956211002.

(20) Risto, M.; Takaluoma, T. T.; Bajorek, T.; Oilunkaniemi, R.; Laitinen, R. S.; Chivers, T. Inorg. Chem. 2009, 48, 6271. doi: 10.1021/ic900551f.

(21) Sandblom, N.; Ziegler, T.; Chivers, T. Inorg. Chem. 1998, 37, 354. doi: 10.1021/ic970680f.

(22) Maaninen, T.; Tuononen, H. M.; Schatte, G.; Suontamo, R.; Valkonen, J.; Laitinen, R.; Chivers, T. Inorg. Chem. 2004, 43, 2097. doi: 10.1021/ic034944b.

(23) Schatte, G.; Chivers, T.; Tuononen, H. M.; Suontamo, R.; Laitinen, R.; Valkonen, J. Inorg. Chem. 2005, 44, 443. doi: 10.1021/ic048565+.

(24) Chivers, T.; Gao, X.; Parvez, M. J. Chem. Soc., Chem. Commun. 1994, 2149. doi: 10.1039/C39940002149.

(25) Chivers, T.; Gao, X.; Parvez, M. J. Am. Chem. Soc. 1995, 117, 2359. doi: 10.1021/ja00113a029.

(26) Chivers, T.; Gao, X.; Parvez, M. Inorg. Chem. 1996, 35, 9. doi: 10.1021/ic950154t.

(27) Chivers, T.; Parvez, M.; Schatte, G. Inorg. Chem. 2001, 40, 540. doi: 10.1021/ic000785+.

(28) Chivers, T.; Schatte, G. Can. J. Chem. 2003, 81, 1307. doi: 10.1139/V03-147.

(29) Chivers, T.; Parvez, M.; Schatte, G. Angew. Chem. Int. Ed. 1999, 38, 2217. doi: 10.1002/(SICI)1521-3773(19990802)38:15<2217::AID-ANIE2217>3.0.CO;2-D.

(30) Chivers, T.; Parvez, M.; Schatte, G. Inorg. Chem. 1999, 38, 5171. doi: 10.1021/ic9903681. 
(31) Karhu, A. J.; Rautiainen, J. M.; Oilunkaniemi, R.; Chivers, T.; Laitinen, R. S., Inorg. Chem., to be published.

(32) Herberhold, M.; Jellen, W. Z. Naturforsch. Teil B, 1986, 41b, 144.

(33) Kharasch, M. S.; Seyler, R. C.; Mayo, F. R. J. Am. Chem. Soc. 1938, 60, 882. doi: 10.1021/ja01271a035.

(34) Chivers, T.; Sandblom, N.; Schatte, G. Inorg. Synth. 2004, 34, 42. doi: 10.1002/0471653683.ch1.

(35) Burns, R. C.; Collins, M. J.; Gillespie, R. J.; Schrobilgen, G. J. Inorg. Chem. 1986, 25, 4465. doi: 10.1021/ic00245a005.

(36) Sheldrick, G. M. Acta Crystallogr., Sect. A 2008, 64A, 112. doi: 10.1107/S0108767307043930.

(37) The ORCA program, version 3.0.3; Neese, F. WIREs Comput. Mol. Sci. 2012, 2, 73. doi: 10.1002/wcms.81.

(38) Perdew, J. P.; Burke, K.; Ernzerhof, M. Phys. Rev. Lett. 1996, 77, 3865. doi: 10.1103/PhysRevLett.77.3865.

(39) Zhang, Y.; Yang, W. Phys. Rev. Lett. 1998, 80, 890. doi: 10.1103/PhysRevLett.80.890.

(40) Perdew, J. P.; Burke, K.; Enrzernhof, M. Phys. Rev. Lett. 1998, 80, 891. doi: 10.1103/PhysRevLett.80.891.

(41) Schäfer, A.; Horn, H.; Ahlrichs, R. J. Chem. Phys. 1992, 97, 2571. doi: 10.1063/1.463096.

(42) Weigend, F.; Ahlrichs, R. Phys. Chem. Chem. Phys. 2005, 7, 3297. doi: 10.1039/B508541A.

(43) Andrae, D.; Häußermann, U.; Dolg, M.; Stoll, H.; Preuß, H. Theor. Chim. Acta 1990, 77, 123. doi: 10.1007/BF01114537.

(44) Weigend, F. Phys. Chem. Chem. Phys. 2006, 8, 1057. doi: 10.1039/B515623H. 
(45) Neese, F. J. Comput. Chem. 2003, 24, 1740. doi: 10.1002/jcc.10318.

(46) Grimme, S.; Ehrlich, S.; Goerigk, L. J. Comput. Chem. 2011, 32, 1456. doi: $10.1002 /$ jcc. 21759 .

(47) Grimme, S.; Antony, J.; Ehrlich, S.; Krieg, H. J. Chem. Phys. 2010, 132, 154104. doi: $10.1063 / 1.3382344$.

(48) Tuononen, H. M.; Suontamo, R. J.; Valkonen, J. U.; Laitinen, R. S.; Chivers, T. Inorg. Chem. 2003, 42, 2447. doi: 10.1021/ic026247+.

(49) Emsley, J., The Elements, 3rd ed. Clarendon Press: Oxford, 1998.

(50) Sgarbosa, P.; Mazzega Sbovata, S.; Bertani, R.; Mozzon, M.; Benetollo, F.; Marzano, C.; Gandin, V.; Michelin, R. A. Inorg. Chem. 2013, 52, 5729. doi: 10.1021/ic3024452.

(51) Maaninen, T.; Chivers, T.; Laitinen, R.; Schatte, G.; Nissinen, M. Inorg. Chem. 2000, 39, 5341. doi: 10.1021/ic000598b.

(52) Maaninen, T.; Laitinen, R.; Chivers, T. Chem. Commun. 2002, 1812. doi: 10.1039/B205011K.

(53) Birchall, T.; Gillespie, R. J.; Vekris, S. L. Can. J. Chem. 1965, 43, 1672. doi: 10.1139/v65221.

(54) Wrackmeyer, B.; Distler, B.; Gerstmann, S.; Herberhold, M. Z. Naturforsch., Teil B 1993, $48 b, 1307$.

(55) Karhu, A. J.; Pakkanen, O. J.; Rautiainen, J. M.; Oilunkaniemi, R.; Chivers, T.; Laitinen, R. S. Inorg. Chem. 2015, 54, 4990. doi: 10.1021/acs.inorgchem.5b00582.

(56) Trueblood, K. N. Acta Crystallogr., Sect. C 1987, 43, 711. doi: 10.1107/S0108270187094411.

(57) Roesky, H. W.; Weber, K.-L.; Bats, J. W. Chem. Ber. 1984, 117, 2686. doi: 10.1002/cber.19841170812. 
(58) Kelly, P. F.; Slawin, A. M. Z.; Williams, D. J.; Woollins, J. D. Polyhedron 1991, 10, 2337. doi:10.1016/S0277-5387(00)86158-6.

(59) Kelly, P. F.; Slawin, A. M. Z.; Soriano-Rama, A. J. Chem. Soc., Dalton Trans. 1996, 53. doi: 10.1039/DT9960000053.

(60) Matuska, V.; Tersago, K.; Kilian, P.; Van Alsenoy, C.; Blockhuys, F.; Slawin, A. M. Z.;

Woollins, J. D. Eur. J. Inorg. Chem. 2009, 4483. doi: 10.1002/ejic.200900541.

(61) Konu, J.; Ahlgrén, M.; Aucott, S. M.; Chivers, T.; Dale, S. M.; Elsegood, M. R. J.;

Holmes, K. E.; James, S. L. M.; Kelly, P. F.; Laitinen, R. S. Inorg. Chem. 2005, 44, 4992. doi: 10.1021/ic050261f.

(62) Epstein, J. M.; White, A. H.; Wild, S. B.; Willis, A. C. J. Chem. Soc., Dalton. Trans. 1974, 436. doi: 10.1039/DT9740000436.

(63) Shimada, S.; Tanaka, M.; Honda, K. J. Am. Chem. Soc. 1995, 117, 8289. doi: 10.1021/ja00136a035.

(64) Duran, N.; Clegg, W.; Fraser, K. A.; González-Duarte, P. Inorg. Chim. Acta 2000, 300302, 790. doi:10.1016/S0020-1693(00)00014-1.

(65) Noro, K.; Ozawa, Y.; Taguchi, M.; Yagasaki, A. Chem. Commun. 2002, 1770. doi: 10.1039/B204804C.

(66) Maaninen, T.; Chivers, T.; Laitinen, R.; Wegelius, E. Chem. Commun. 2000, 759. doi: 10.1039/B001002M.

(67) Bates, C. M.; Khanna, P. K.; Morley, C. P.; Di Vaira, M. Chem. Commun. 1997, 913. doi: 10.1039/A607904K.

(68) Belluco, U.; Benetollo, F.; Bertani, R.; Bombieri, G.; Michelin, R. A.; Mozzon, M.; Tonon, O.; Pombeiro, A. J. L.; Costa Guedes de Silva, F. Inorg. Chim. Acta 2002, 334, 437. doi:10.1016/S0020-1693(02)00866-6. 
(69) Maaninen, A.; Chivers, T.; Parvez, M.; Pietikäinen, J.; Laitinen, R. S. Inorg. Chem. 1999, 38, 4093. doi: 10.1021/ic981430h. 
Table 1. Details of the structure determinations of $1,2,3 \cdot 3 \mathrm{MeCN}$, and $4 \cdot 2 \mathrm{THF}$.

\begin{tabular}{|c|c|c|c|c|}
\hline & 1 & 2 & 3.3MeCN & $\mathbf{4} \cdot 2 \mathrm{THF}$ \\
\hline Empirical Formula & $\mathrm{C}_{8} \mathrm{H}_{18} \mathrm{Cl}_{2} \mathrm{~N}_{2} \mathrm{PtSe}$ & $\mathrm{C}_{8} \mathrm{H}_{20} \mathrm{Cl}_{2} \mathrm{~N}_{2} \mathrm{OPtSe}$ & $\mathrm{C}_{30} \mathrm{H}_{63} \mathrm{Cl}_{8} \mathrm{~N}_{9} \mathrm{Pt}_{3} \mathrm{Se}_{7}$ & $\mathrm{C}_{15} \mathrm{H}_{23} \mathrm{Cl}_{3} \mathrm{~N}_{2} \mathrm{OPtSe}$ \\
\hline Formula weight & 487.19 & 505.21 & 1971.48 & 837.01 \\
\hline Crystal system & orthorhombic & monoclinic & monoclinic & monoclinic \\
\hline Space group & Pbca & $P 2_{1} / c$ & $\mathrm{Cm}$ & $P 2{ }_{1} / n$ \\
\hline$a(\AA)$ & $13.479(3)$ & $10.318(2)$ & $17.434(5)$ & $11.648(2)$ \\
\hline$b(\AA)$ & $11.032(2)$ & $16.462(3)$ & $10.913(5)$ & $10.293(2)$ \\
\hline$c(\AA)$ & $18.358(4)$ & $9.0157(18)$ & $15.833(5)$ & $17.338(4)$ \\
\hline$\beta\left(^{\circ}\right)$ & & $113.72(3)$ & $113.525(5)$ & $105.55(3)$ \\
\hline$V\left(\AA^{3}\right)$ & 2729.7(9) & $1402.0(6)$ & $2762.0(17)$ & $2002.7(7)$ \\
\hline$T(\mathrm{~K})$ & $100(2)$ & $120(2)$ & $150(2)$ & $100(2)$ \\
\hline$Z$ & 8 & 4 & 2 & 4 \\
\hline$F(000)$ & 1808 & 944 & 1828 & 1192 \\
\hline$D_{c}\left(\mathrm{~g} \mathrm{~cm}^{-1}\right)$ & 2.371 & 2.394 & 2.371 & 2.082 \\
\hline$\mu\left(\mathrm{Mo}-\mathrm{K}_{\alpha}\right)\left(\mathrm{mm}^{-1}\right)$ & 13.308 & 12.965 & 12.611 & 9.228 \\
\hline Crystal size (mm) & $0.5 \times 0.15 \times 0.02$ & $0.1 \times 0.05 \times 0.05$ & $0.2 \times 0.1 \times 0.1$ & $0.2 \times 0.1 \times 0.03$ \\
\hline$\theta$ range (deg.) & $2.63-26.00$ & $3.50-25.00$ & $3.18-26.00$ & $2.69-26.00$ \\
\hline $\begin{array}{l}\text { Number of reflections } \\
\text { collected }\end{array}$ & 10975 & 7474 & 9586 & 20825 \\
\hline $\begin{array}{l}\text { Number of unique } \\
\text { reflections }\end{array}$ & 2647 & 2439 & 5143 & 3930 \\
\hline $\begin{array}{l}\text { Number of observed } \\
\text { reflections }{ }^{a}\end{array}$ & 2355 & 2010 & 4963 & 3613 \\
\hline Number of parameters & 128 & 107 & $260 / 20$ & 211 \\
\hline $\mathrm{R}_{I N T}$ & 0.1143 & 0.1096 & 0.0488 & 0.0696 \\
\hline $\mathrm{R}_{l}^{b}$ & 0.0470 & 0.0641 & 0.0369 & 0.0368 \\
\hline$w R_{2}{ }^{b}$ & 0.1219 & 0.1412 & 0.0929 & 0.0858 \\
\hline $\mathrm{R}_{l}$ (all data) & 0.0550 & 0.0822 & 0.0394 & 0.0424 \\
\hline $\mathrm{wR}_{2}($ all data $)$ & 0.1281 & 0.1515 & 0.0955 & 0.0880 \\
\hline GOOF & 1.127 & 1.109 & 1.050 & 1.108 \\
\hline $\begin{array}{l}\text { Max. and min. heights in } \\
\text { final difference Fourier } \\
\text { synthesis }\left(\mathrm{e} \AA^{-3}\right)\end{array}$ & $2.254,-2.219$ & 1.856. -2.000 & $2.039,-0.790$ & $1.149,-2.348$ \\
\hline
\end{tabular}

${ }^{a} I \geq 2 \sigma(I) .{ }^{b} \mathrm{R}_{I}=\Sigma|| F_{o}|-| F_{c}|| \sum\left|F_{o}\right|, w R_{2}=\left[\sum w\left(F_{o}{ }^{2}-F_{c}{ }^{2}\right)^{2} \Sigma w w F_{o}{ }^{4}\right]^{1 / 2}$. 


\section{Figure Captions}

Fig. 1. The molecular structure of $\left[\operatorname{PtCl}_{2}\left\{N, N^{\prime}-\mathrm{Se}[\mathrm{N}(\mathrm{t}-\mathrm{Bu})]_{2}\right\}\right]$ (1) indicating the numbering of the atoms. Thermal ellipsoids are drawn at $50 \%$ probability level. Selected bond lengths $(\AA)$ and angles $\left(^{\circ}\right)$ : Pt1-N1 2.030(6), Pt1-N2 2.022(7), Pt1-Cl1 2.297(2), Pt1-Cl2 2.284(2), Se1-N1 1.751(6), Se1-N2 1.743(6), N1-Pt1-N2 73.0(3), N1-Pt1-Cl1 100.5(2), N1-Pt1-Cl2 171.8(2), Cl1Pt1-Cl2 87.55(8), Cl1-Pt1-N2 173.5(2), Cl2-Pt1-N2 98.9(2), N1-Se1-N2 87.3(3).

Fig. 2. The molecular structure of $\left[\mathrm{PtCl}_{2}\left\{N, N^{\prime}-\mathrm{SeO}[\mathrm{NH}(\mathrm{t}-\mathrm{Bu})]_{2}\right\}\right]$ (2) indicating the numbering of the atoms. Thermal ellipsoids are drawn at $50 \%$ probability level. The s.o.f. of the two disordered molecules are $0.9738(15)$ and $0.0262(15)$. Selected bond lengths $(\AA)$ and angles $\left(^{\circ}\right)$ in the more abundant orientation (complex A): Pt1A-N1A 2.072(12), Pt1A-N2A 2.072(12), Pt1ACl1 2.318(4), Pt1A-Cl2 2.320(4), Se1A-N1A 1.907(12), Se1A-N2A 1.937(13), Se1A-O1A 1.633(11), N1A-C10 1.55(2), N2A-C20 1.52(2), N1A-Pt1A-N2A 76.4(5), N1A-Pt1A-Cl1 98.5(3), N1A-Pt1A-Cl2 174.1(3), Cl1-Pt1A-Cl2 87.16(15), Cl1-Pt1A-N2A 174.3(3), Cl2-Pt1AN2A 97.8(4), N1A-Se1A-N2A 83.7(5), N1A-Se1A-O1A 103.6(5), O1A-Se1A-N2A 104.9(5), Se1A-N1A-C10 112.9(10), Se1A-N1A-Pt1A 98.2(6), C10-N1A-Pt1A 125.6(10), Se1A-N2AC20 110.9(10), Se1A-N2A-Pt1A 97.3(5), C20-N2A-Pt1A 126.6(10).

Fig. 3. The ${ }^{77} \mathrm{Se}$ NMR spectrum of the soluble portion of the reaction mixture of $\mathrm{SeOCl}_{2}$ and $\mathrm{t}$ $\mathrm{BuNH}_{2}$ in THF. 
Fig. 4. Gibbs energy profile $\left[\Delta \mathrm{G}(298 \mathrm{~K}) ; \mathrm{kJ} \mathrm{mol}^{-1}\right]$ of the reaction of $\mathrm{Se}[\mathrm{N}(\mathrm{t}-\mathrm{Bu})]_{2}$ and $\mathrm{H}_{2} \mathrm{O}$ calculated at the revPBE/def2-TZVP level.

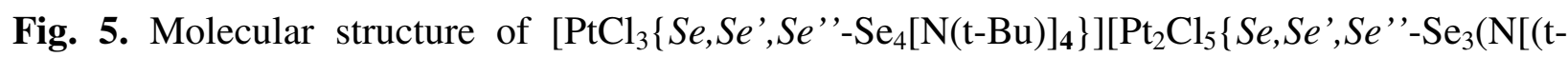
$\left.\left.\mathrm{Bu})]_{2}\right\}\right] \cdot 3 \mathrm{MeCN}(3 \cdot 3 \mathrm{MeCN})$ indicating the numbering of selected atoms. Thermal ellipsoids are drawn at $50 \%$ probability level. For clarity, only the more abundant orientations of the tert-butyl groups are shown in the figure. Selected bond lengths $(\AA)$ and angles $\left(^{\circ}\right)$ : Pt1-Se1 2.381(3), Pt1Se2 2.4383(17), Pt1-Cl11 2.318(6), Pt1-Cl12 2.366(4), Pt2-Se4 2.4240(17), Pt2-Se5 2.399(2), Pt2-Cl21 2.362(5), Pt2-Cl22 2.365(6), Pt3-Se4 2.3617(17), Pt3-Cl31 2.342(4), Se1-N1 1.858(14), Se2-N1 1.836(14), Se2-N2 1.811(12), Se3-N2 1.853(12), Se4-N3 1.880(13), Se5-N3 1.840(14), Se1-Pt1-Se2 77.06(5), Se1-Pt1-C111 170.65(18), Se2-Pt1-Se2 ${ }^{i}$ 100.82(8), Cl11-Pt1Cl12 91.43(17), Cl12-Pt1-Cl12 ${ }^{i}$ 97.5(2), Se4-Pt3-Se4 ${ }^{i}$ 85.03(8), Cl31-Pt3-Se4 91.23(12), Cl31Pt3-Se4 ${ }^{i}$ 176.15(12), Cl31-Pt3-Cl31 ${ }^{i}$ 92.5(2), Se4-Pt2-Se5 77.07(6), Se4-Pt2-Se4 ${ }^{i}$ 82.36(8), Se5Pt2-Cl21 95.13(13), Se5-Pt2-Cl22 167.90(17), Cl21-Pt2-Cl22 93.23(17), Cl21-Pt2-Cl21 ${ }^{i}$ 92.4(3), N1-Se1-N1 ${ }^{i}$ 100.9(10), Se1-N1-Se2 108.7(7), Se2-N2-Se3 119.9(7), N2-Se3-N2 ${ }^{i}$ 103.7(8), Se4N3-Se5 107.7(6), N3-Se5-N3 ${ }^{i} 112.0(9)$. The symmetry operation $(i): x,-y, z$.

Fig. 6. The ${ }^{77} \mathrm{Se} N M R$ spectra of the reaction solution from the reaction of $\mathrm{Se}[\mathrm{N}(\mathrm{t}-\mathrm{Bu})]_{2}$ and $\left[\mathrm{PtCl}_{2}(\mathrm{NCPh})_{2}\right]$. (a) Molar ratio 1:1, (b) molar ratio 2:1.

Fig. 7. The molecular structure of $\left[\mathrm{Pt}_{2} \mathrm{Cl}_{6}\{\mathrm{SeN}(\mathrm{t}-\mathrm{Bu}) \mathrm{C}(\mathrm{Ph}) \mathrm{NH}\}_{2}\right] \cdot 2 \mathrm{C}_{4} \mathrm{H}_{8} \mathrm{O}(\mathbf{4} \cdot 2 \mathrm{THF})$ indicating the numbering of the atoms. Thermal ellipsoids are drawn at $50 \%$ probability level. Selected bond lengths $(\AA)$ and angles $\left(^{\circ}\right)$ : Pt1-Se1 2.3790(7), Pt1-Se1 ${ }^{i}$ 2.4482(8), Pt1-N1 2.024(5), Pt1- 
Cl1 2.3518(15), Pt1-Cl2 2.3293(15), Pt1-Cl3 2.3598(16), Se1-N2 1.865(5), N1-C1 1.315(8), N2C1 1.359(8), N1-Pt1-Cl1 94.61(16), N1-Pt1-Cl2 172.61(16), N1-Pt1-Cl3 85.45(16), N1-Pt1-Se1 82.10(15), N1-Pt1-Se1 ${ }^{i}$ 86.99(16), Se1-Pt1-Se1 ${ }^{i}$ 86.00(3), Se1-Pt1-Cl1 173.78(4), Se1-Pt1-Cl2 91.80(4), Se1-Pt1-Cl3 91.71(5), Se1 ${ }^{i}-\mathrm{Pt} 1-\mathrm{Cl} 1$ 88.57(5), Se1 ${ }^{i}-\mathrm{Pt} 1-\mathrm{Cl} 2$ 96.77(4), Se1 ${ }^{i}-\mathrm{Pt} 1-\mathrm{Cl} 3$ 172.33(4), Cl1-Pt1-Cl2 91.85(6), Cl1-Pt1-Cl3 93.29(6), Cl2-Pt1-Cl3 90.61(6), Pt1-Se1-Pt1 ${ }^{i}$ 94.00(3), Pt1-Se1-N2 94.03(15), Pt1 ${ }^{i}$-Se1-N2 106.62(16), Se1-N2-C1 115.3(4), Se1-N2-C20 116.6(4), C1-N2-C20 128.0(5), Pt1-N1-C1 120.8(4). Symmetry operation (i): 2-x, 1-y, -z.

Fig. 8. The revPBE/def2-TZVP Gibbs energy profile of the oxidative addition leading to the formation of the dinuclear platinum(IV) complex 4.

Scheme 1. A possible formation of $\mathbf{3}$ via a redox process.

Scheme 2. A possible pathway for the formation of 4 from $\left[\mathrm{PtCl}_{2}(\mathrm{NCPh})_{2}\right]$

Scheme 3. The reaction of cyclohepteno-1,4-diselenin with $\left[\mathrm{MCl}_{2}(\mathrm{NCPh})_{2}\right](\mathrm{M}=\mathrm{Pd}, \mathrm{Pt}) .{ }^{67}$

Chart 1. Coordination modes in chalcogen diimide complexes.

Chart 2. Complexes 1-4. 


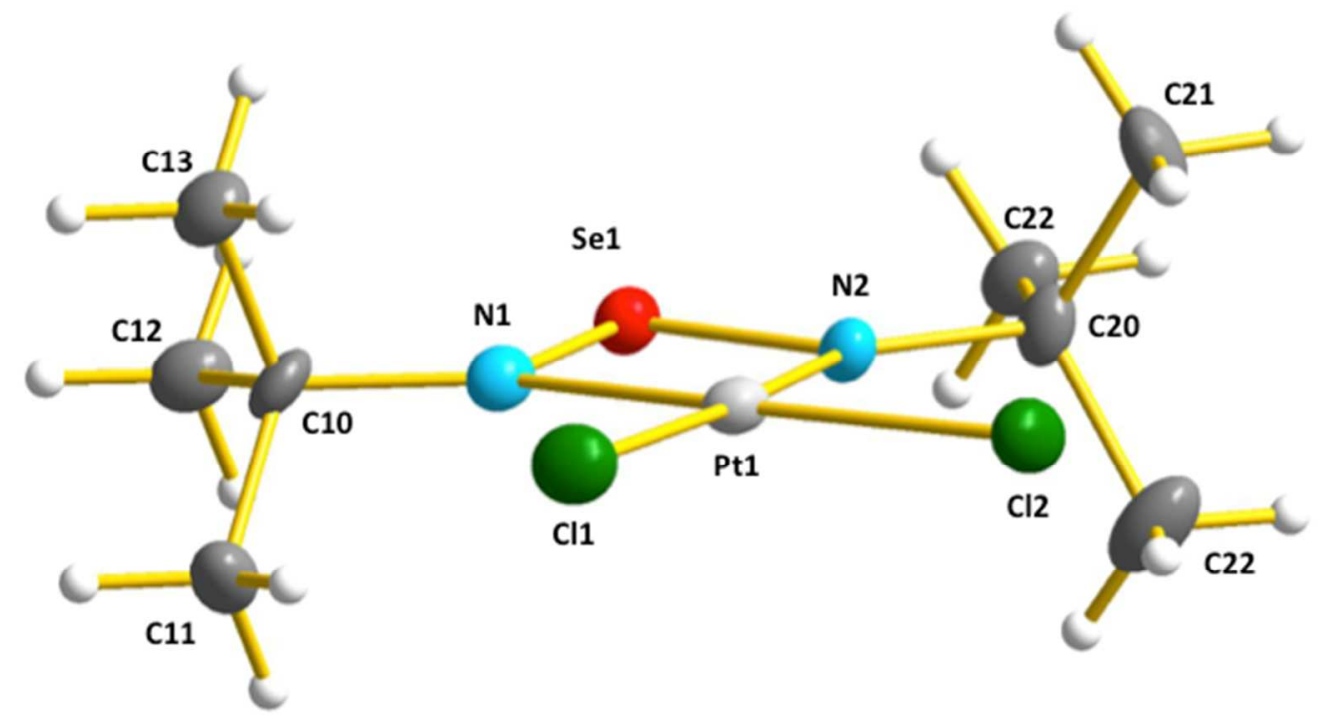

Fig. 1. 


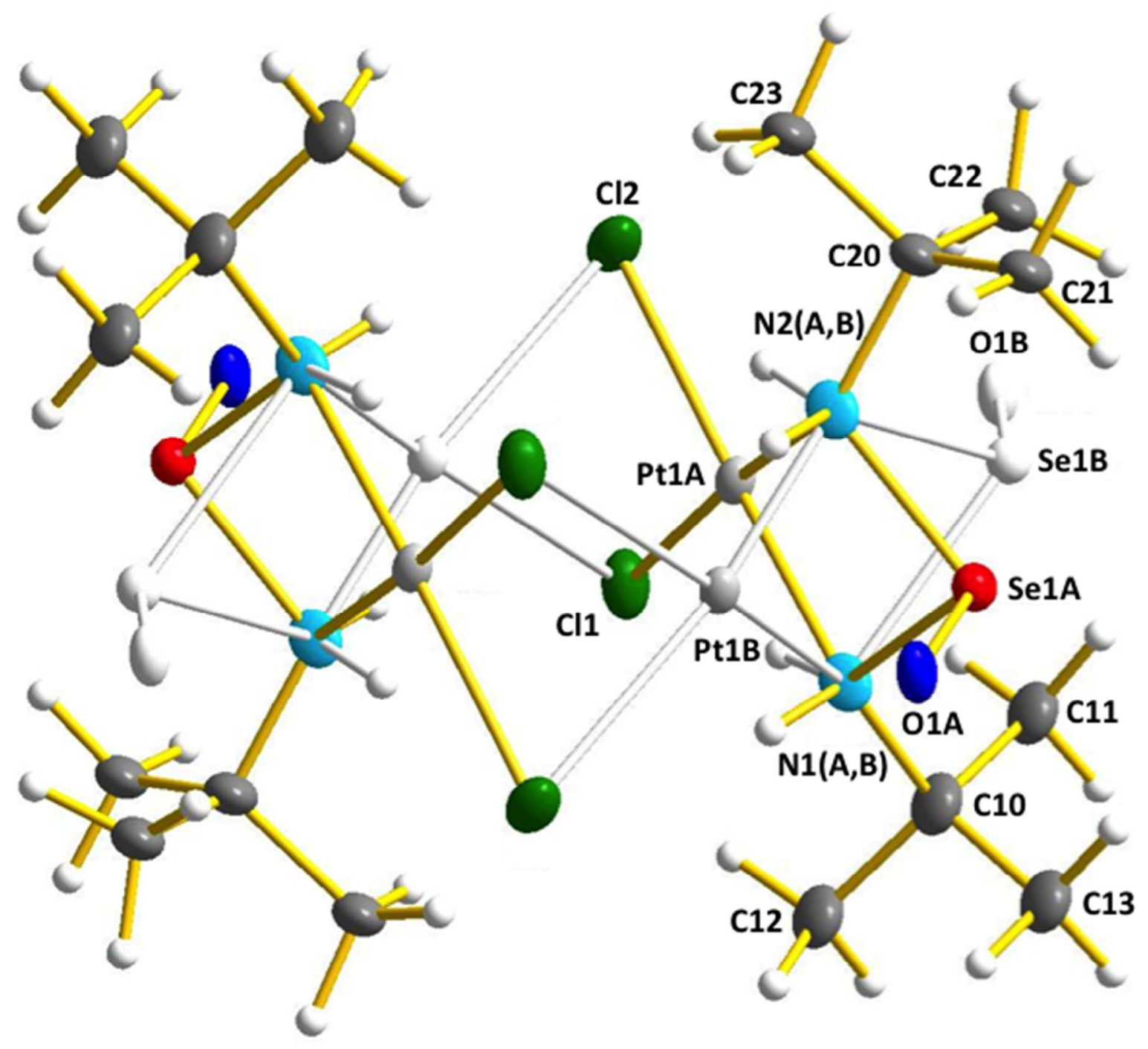

Fig. 2 


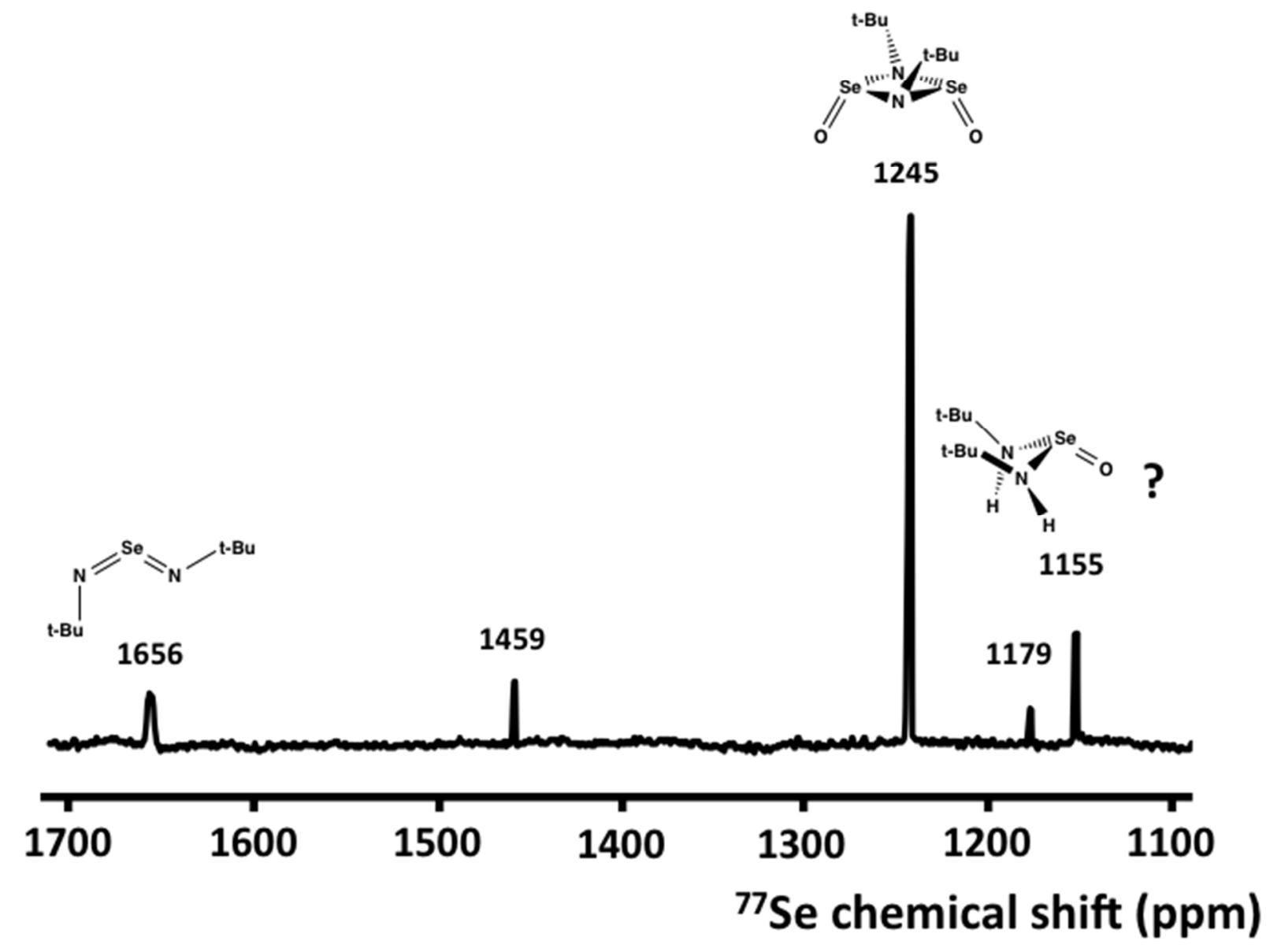

Fig. 3 


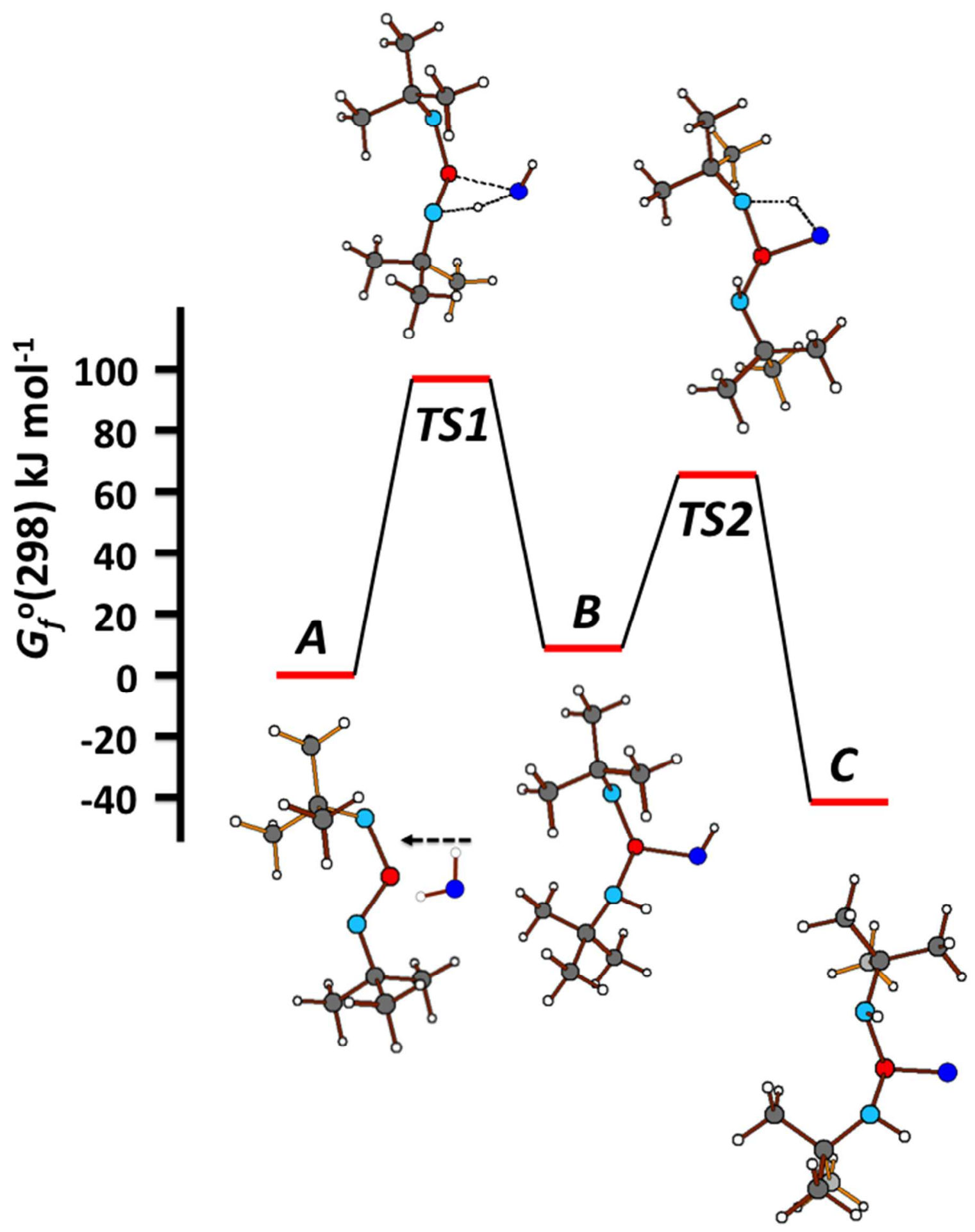

Fig. 4 


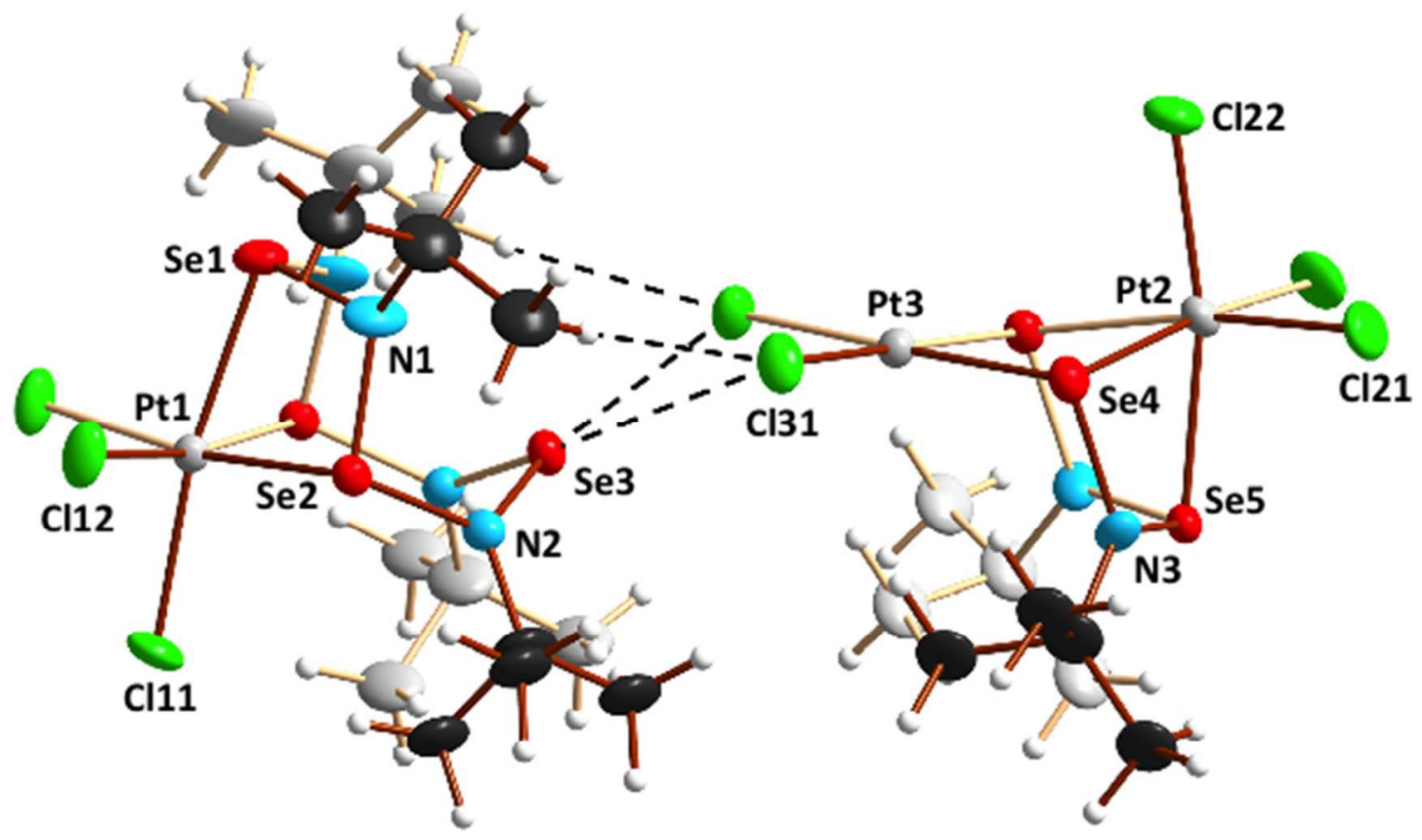

Fig. 5 


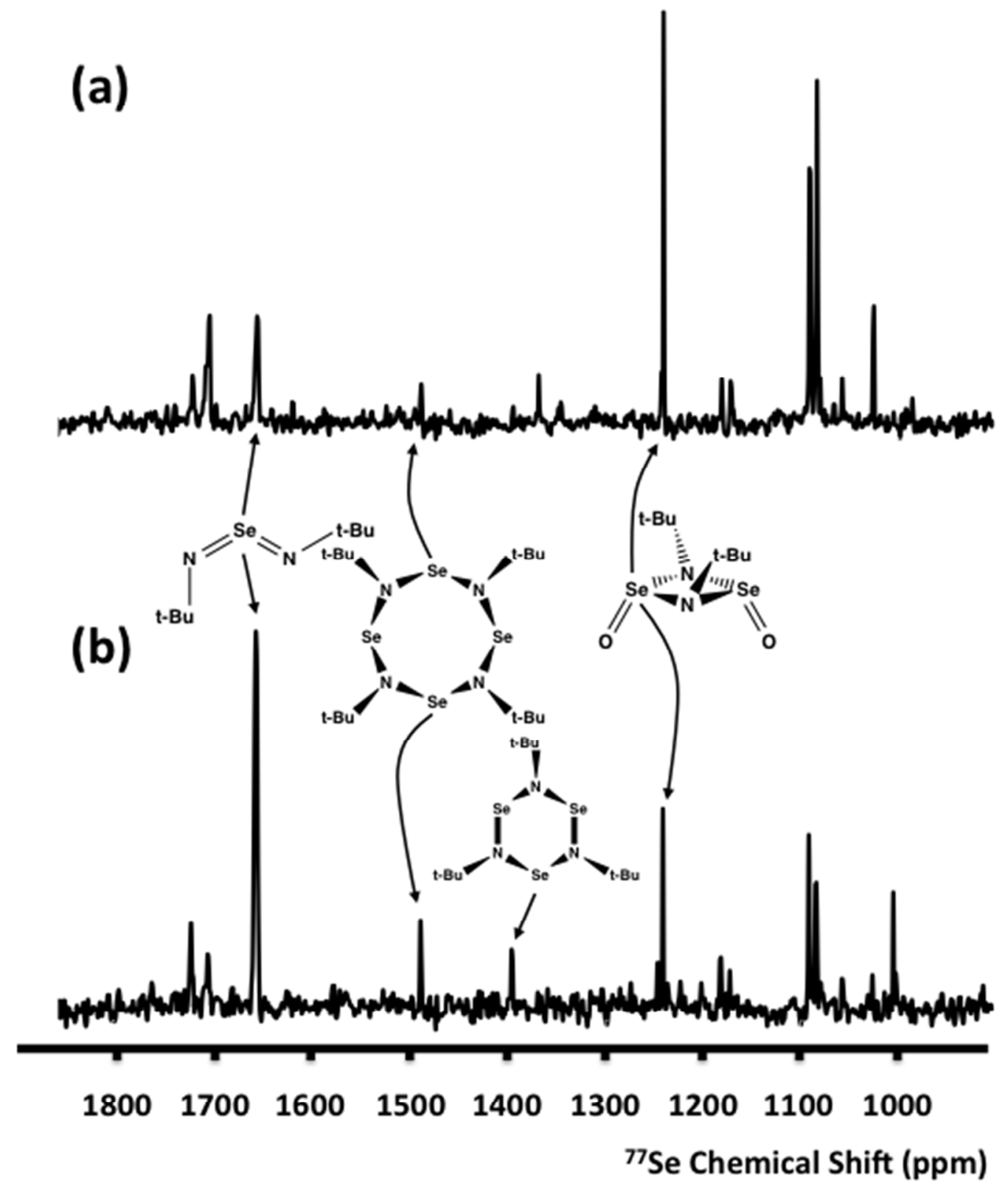

Fig. 6 


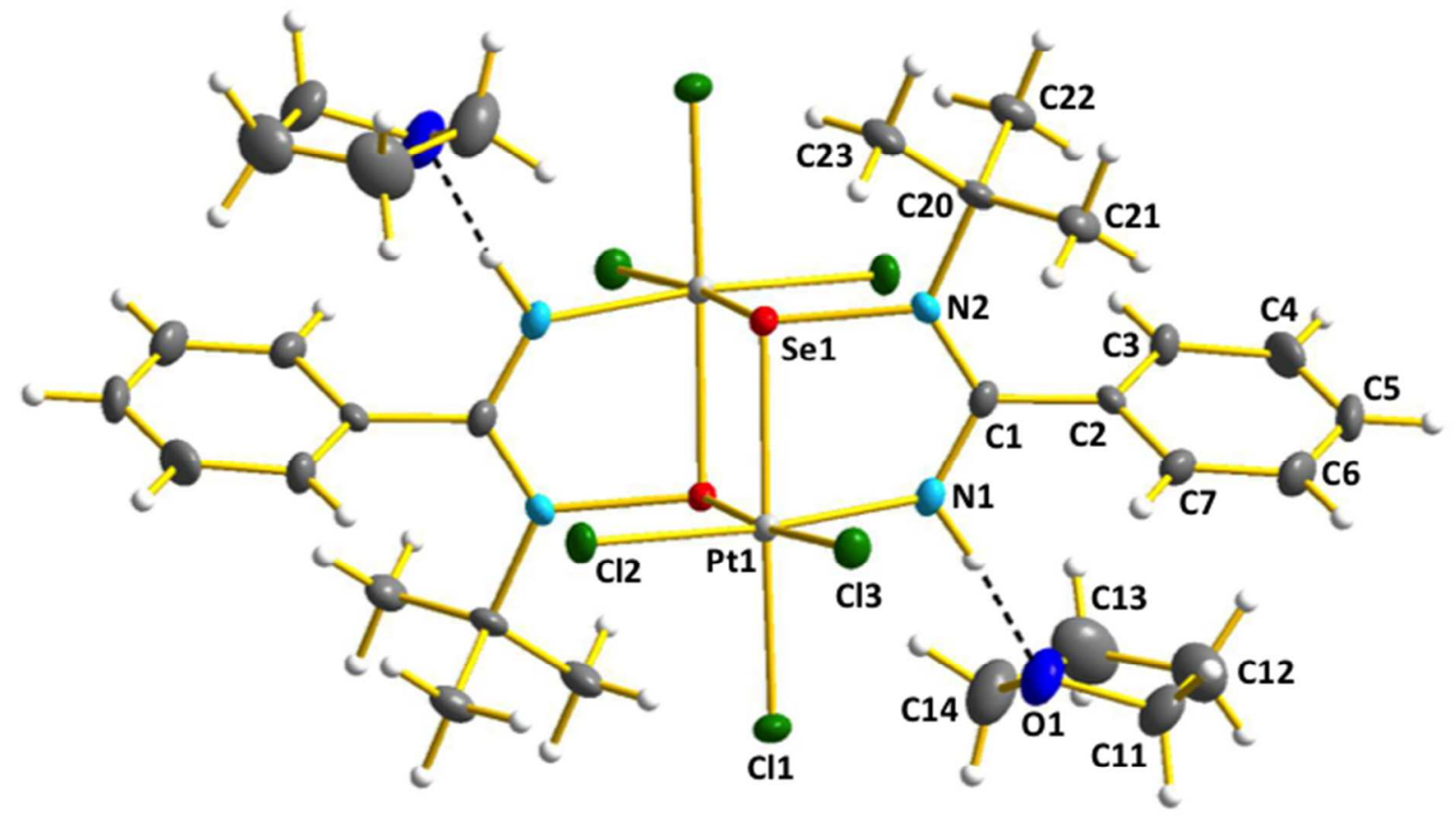

Fig. 7 


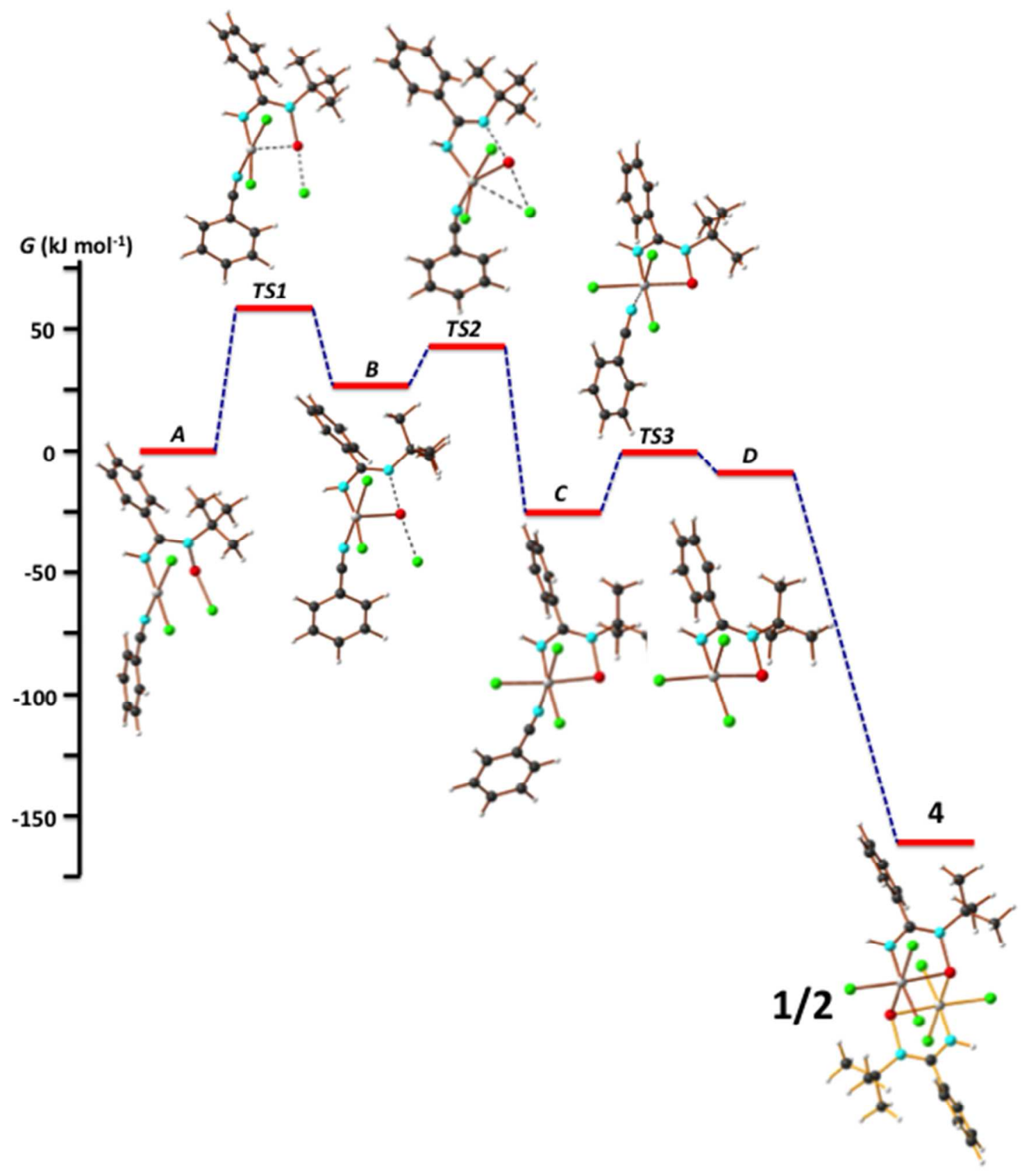

Fig. 8 

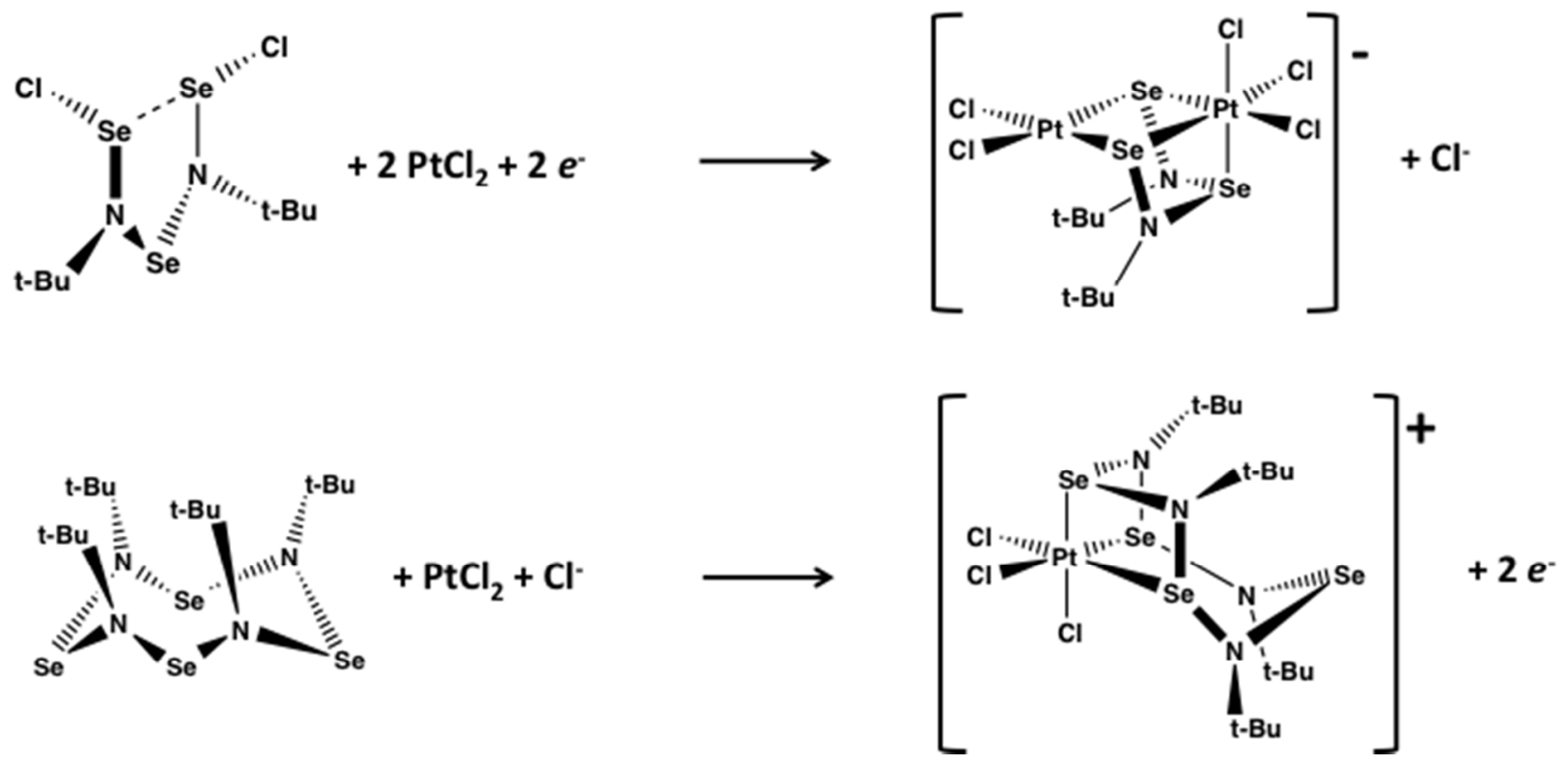

Scheme 1. 

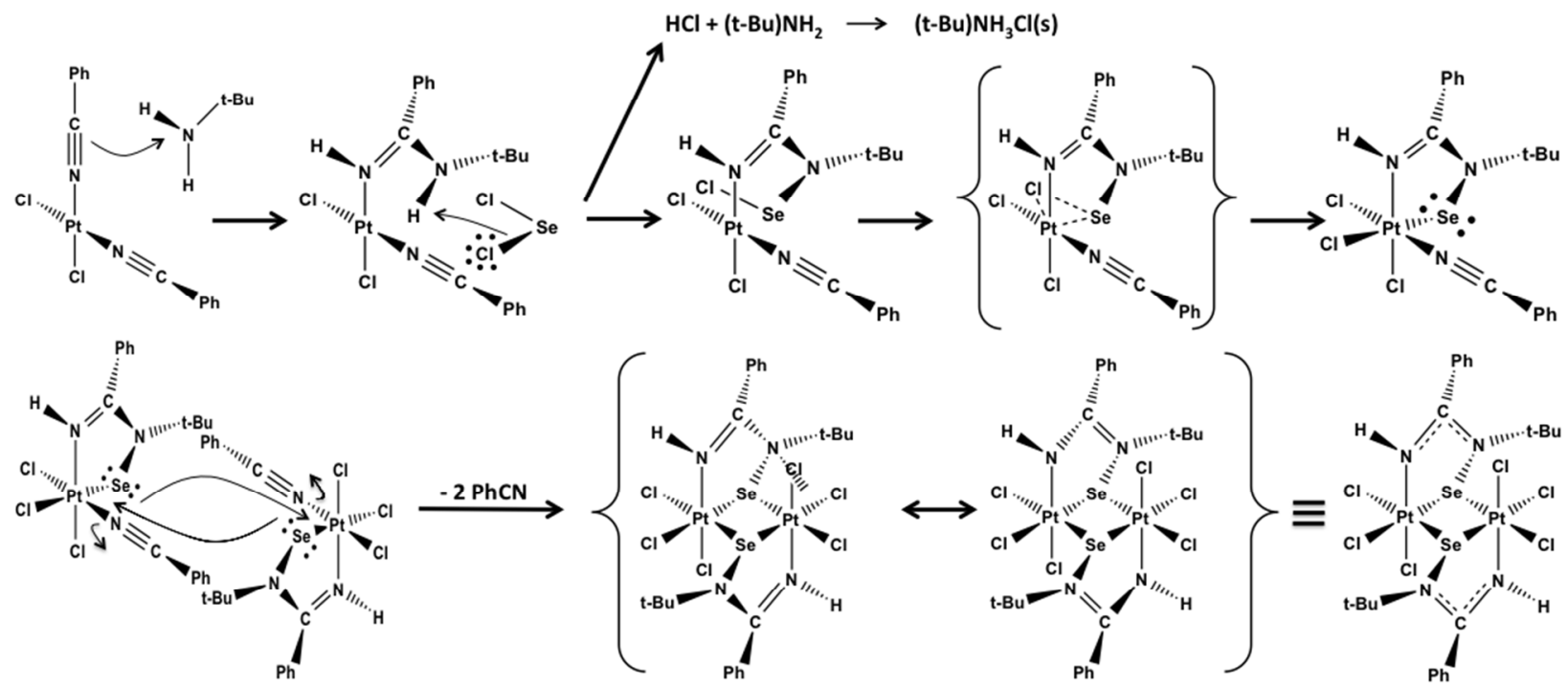

Scheme 2 

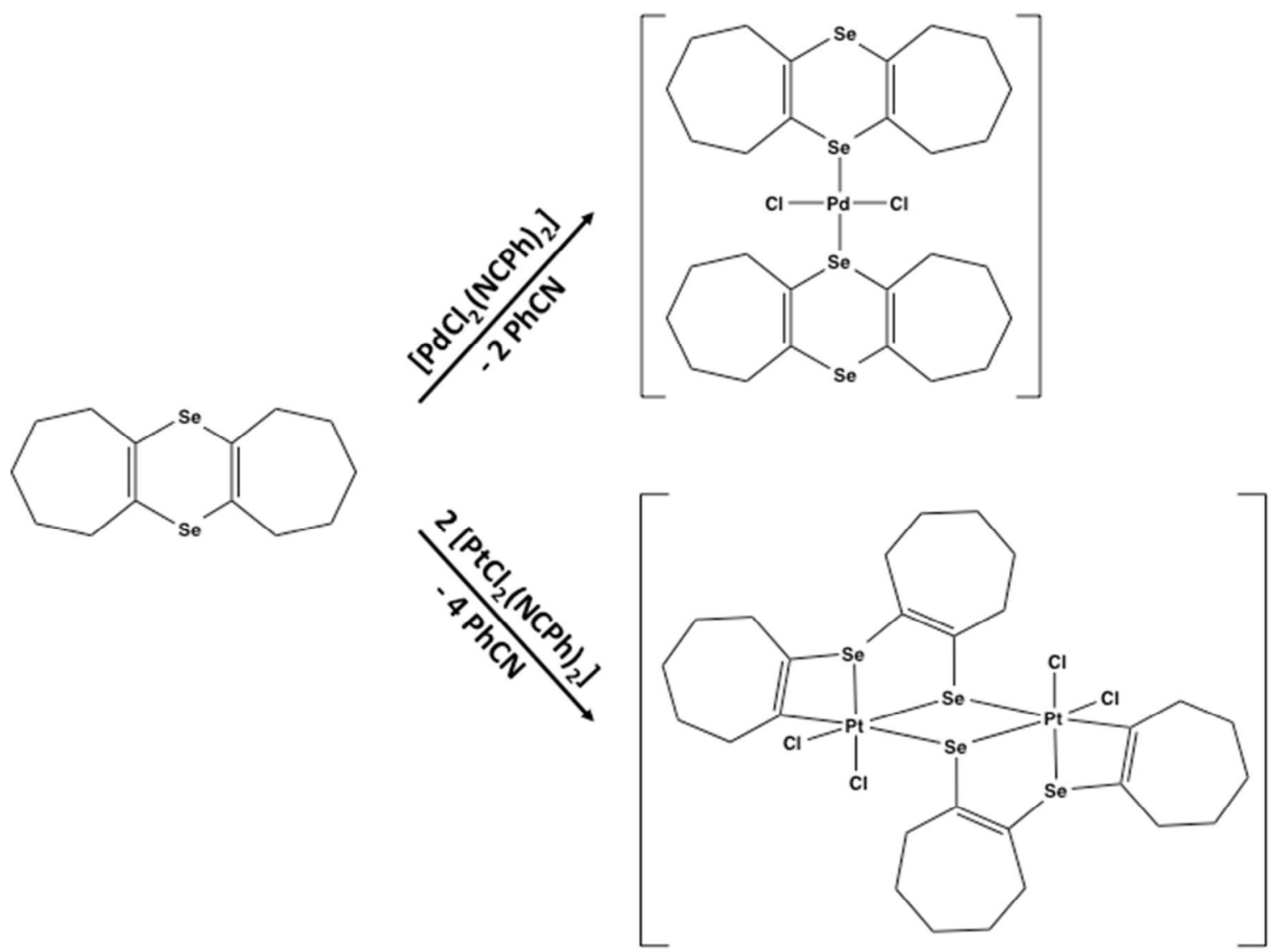

Scheme 3. 


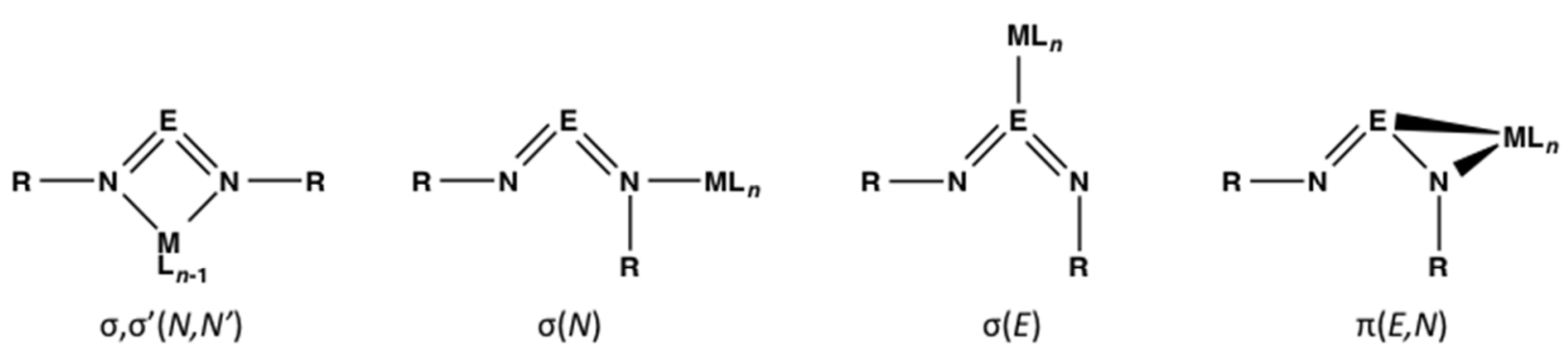

Chart 1 


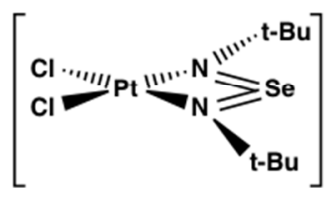

1

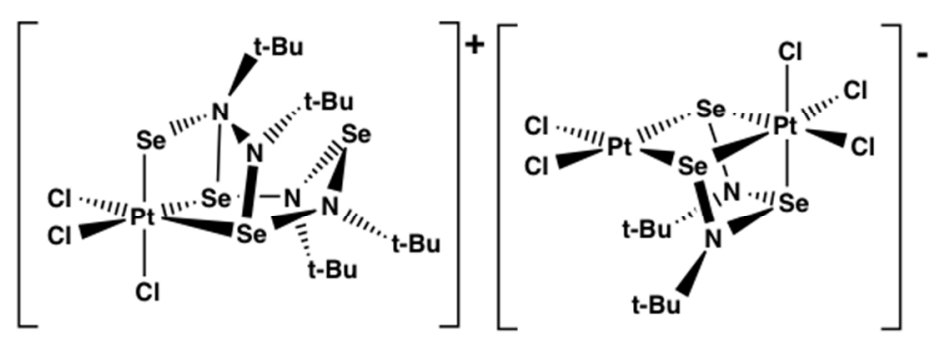

3

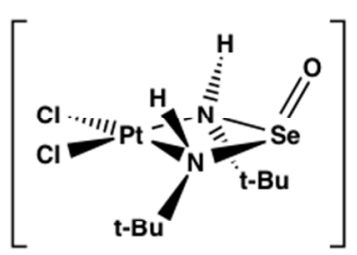

2

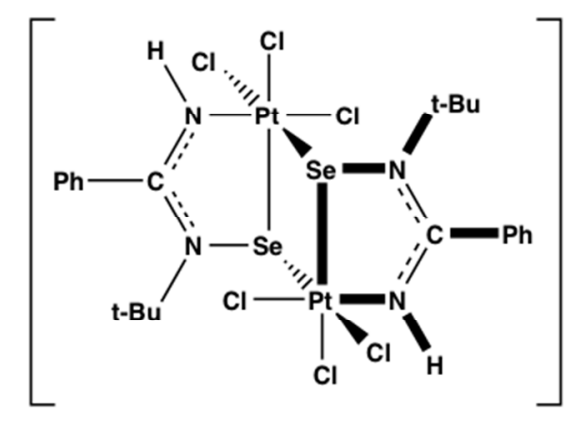

4

Chart 2. 
(Graphical abstract entry)

Experimental and computational investigations of platinum complexes of selenium diimide and some novel selenium-nitrogen ligands

Aino J. Karhu, Maarit Risto, J. Mikko Rautiainen, Raija Oilunkaniemi, Tristram Chivers, and Risto S. Laitinen

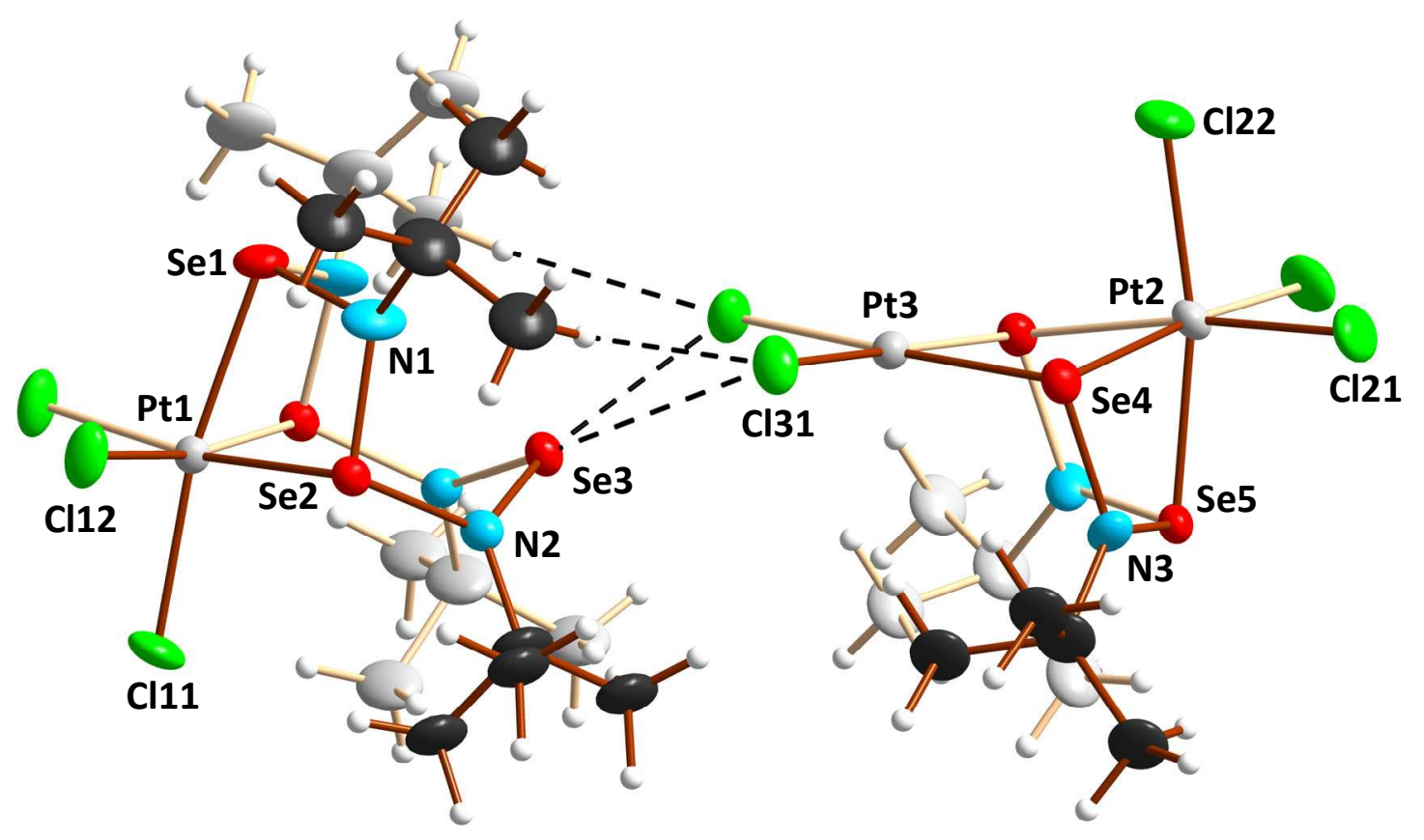

